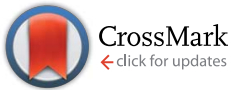

Cite this: RSC Adv., 2015, 5, 72995
Received 7th June 2015

Accepted 14th August 2015

DOI: $10.1039 / \mathrm{c} 5 \mathrm{ra10785g}$

www.rsc.org/advances

\section{New antimalarial 3-methoxy-1,2-dioxanes: optimization of cellular pharmacokinetics and pharmacodynamics properties by incorporation of amino and $\mathrm{N}$-heterocyclic moieties at $\mathrm{C} 4 \uparrow$}

\author{
D. P. Sonawane, $t^{\mathrm{a}}$ M. Persico, ${ }^{\text {be }}$ Y. Corbett, ${ }^{\text {ce }}$ G. Chianese, ${ }^{\text {be }}$ A. Di Dato, ${ }^{\text {be }}$ \\ C. Fattorusso, ${ }^{\text {tbe }}$ O. Taglialatela-Scafati, ${ }^{\text {be }} \mathrm{D}$. Taramelli, ${ }^{\text {ce }} \mathrm{C}$. Trombini, ${ }^{\text {de }}$ \\ D. D. Dhavale, ${ }^{a}$ A. Quintavalla ${ }^{\text {de }}$ and M. Lombardo*de
}

\begin{abstract}
A new series of nineteen 3-methoxy-1,2-dioxanes containing an amino moiety at C4 was designed, synthesized and tested for in vitro antimalarial activity against chloroquine sensitive (CQ-S) D10 and chloroquine resistant (CQ-R) W2 strains of Plasmodium falciparum (Pf). Cytotoxicity against the human endothelial cell line (HMEC-1) was also evaluated. The introduced modifications resulted in a notable improvement of the antimalarial activity. In particular, compound 9a with an amino-imidazole side-chain at C4 displays antimalarial activity in the high nanomolar range against the $C Q-R$ Pf strain $\left(\mathrm{W} 2 \mathrm{IC}_{50}=\right.$ $200 \mathrm{nM}$ ), being more active against CQ-R than CQ-S Pf strains and devoid of cytotoxicity against human HMEC-1 cells. On the other hand, some of the hybrids with 4-amino-7-chloroquinoline (9k-p) show an $I C_{50}$ comparable to that of chloroquine against the CQ-S Pf strain $\left(9 \mathrm{k}-\mathrm{p}, \mathrm{D} 10 \mathrm{IC} \mathrm{C}_{50}=50-90 \mathrm{nM}\right)$ but without losing potency against the $C Q-R$ Pf strain $(9 k-p$, resistance index $=1.2-2.6)$, with low cytotoxicity against HMEC-1. Structure-activity relationship studies show that the improved antimalarial activity of the new compounds is the result of a combination of cellular pharmacokinetics and pharmacodynamics effects.
\end{abstract}

\section{Introduction}

A number of peroxide-containing metabolites belonging to the classes of terpenes, polyketides and phenolics have been isolated from medicinal plants and marine organisms ${ }^{1}$ showing potent antitumor and antimalarial activities. The lead compound in the family of antimalarials is artemisinin, a sesquiterpene lactone containing a 1,2,4-trioxane ring, isolated from the plant Artemisia annua, a herb employed in Chinese traditional medicine. Artemisinin (1a) and its semi-synthetic

${ }^{a}$ Garware Research Centre, Department of Chemistry, Savitribai Phule Pune University (Formerly University of Pune), Pune-411007, India

${ }^{b}$ Dipartimento di Farmacia, Università di Napoli "Federico II", via D. Montesano 49, 80131 Napoli, Italy. E-mail: caterina.fattorusso@unina.it

${ }^{c}$ Dipartimento di Scienze Farmacologiche e Biomolecolari, Università di Milano, via Pascal 36, 20133 Milano, Italy

'Dipartimento di Chimica "Giacomo Ciamician”, Alma Mater Studiorum, Università di Bologna, via Selmi 2, 40126 Bologna, Italy.E-mail: marco.lombardo@unibo.it ${ }^{e}$ Italian Malaria Network - Centro Interuniversitario di Ricerche Sulla Malaria (CIRM), Dipartimento di Medicina Sperimentale e Scienze Biochimiche, via Del Giochetto, 06126 Perugia, Italy

$\dagger$ Electronic supplementary information (ESI) available: Copies of ${ }^{1} \mathrm{H}$ and ${ }^{13} \mathrm{C}$ NMR spectra, data relative to conformational calculations. See DOI: 10.1039/c5ra10785g

\$ These authors equally contributed to the work. derivatives such as dihydroartemisinin (1b), artemether (1c), artemotil (1d), artesunate (1e) and artelinic acid (1f) (Fig. 1), are the main components of artemisinin-based combination therapies (ACTs), the first-line treatment for Plasmodium falciparum $(P f)$ malaria in disease-endemic countries, as recommended by

Inspired by the pool of natural peroxides, over the last three decades the scientific community has given special attention to the design, synthesis and development of fully synthetic peroxides such as 1,2,4,5-tetraoxanes, 1,2,4-trioxanes, 1,2-dioxanes, 1,2-dioxolanes and 1,2,4-trioxolanes (ozonides). ${ }^{3}$

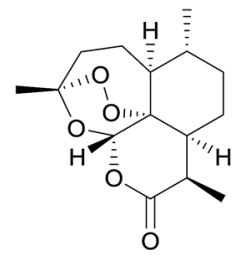

$1 \mathrm{a}$

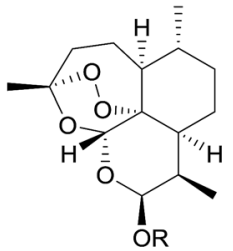

1b: $R=H, 1 c: R=M e, 1 d: R=E t$ 1e: $\mathrm{R}=\mathrm{HOOC}\left(\mathrm{CH}_{2}\right)_{2} \mathrm{C}=\mathrm{O}$ 1f: $\mathrm{R}=4-(\mathrm{COOH})-\mathrm{PhCH}_{2}$
Fig. 1 Artemisinin (1a) and its semi-synthetic analogues $1 b-f$. the World Health Organization (WHO). ${ }^{2}$ 
Just to give an idea of this effort, a joint report ${ }^{4}$ by Medicine for Malaria Venture (MMV) and ChEMBL lists more than 200 molecules containing the 1,2-dioxane ring, more than 1000 containing the 1,2,4-trioxane ring, more than 300 containing the 1,2,4,5-tetraoxane ring and about 150 containing the 1,2,4-trioxolane ring.

Prompted by our studies on the relatively simple structure of plakortin (2a), isolated from the Caribbean sponges Plakortis sp along with several congeners (e.g. 2b-d, Fig. 2), ${ }^{5,6}$ we recently reported an approach to the synthesis of endoperoxides 4 via the hemiacetal 3, through a straightforward and practical two-step synthesis based on a formal $[2+2+2]$ free radical cycloaddition of a gem-disubstituted alkene, a $\beta$-ketoester and $\mathrm{O}_{2}$ (Scheme 1). ${ }^{7}$

Since this approach fulfilled a key MMV recommendation (http://www.mmv.org), namely to use cheap and practical synthetic methodologies, the new family of 1,2-dioxanes 4 was tested against strains of $P f$ with different drug resistance phenotype. Although in these early studies the antimalarial activity $\left(\mathrm{IC}_{50}\right)$ of $\mathbf{4}$ was only in the micromolar range, we took advantage of the synthetically flexible structure in our hands, and we started a broader investigation based on our previously developed plakortin pharmacophore model. ${ }^{6}$ The ester functionality at C4 was modified into an alcohol $(5),{ }^{8}$ ether $(6)^{8}$ or amide group (7) ${ }^{9}$ and a 3 D-SAR study was performed on all the members of our library of about 50 compounds $4-7 .^{7-9}$ The results were consistent with the so called C-radical hypothesis, where the peroxide group of 4-7 undergoes one electron reductive bioactivation to generate first $\mathrm{O}$-radicals which then collapse to C-radicals that are held to be the cytotoxic agents. ${ }^{10}$ Even though we are aware that alternative models have been proposed for the mechanism of action of peroxides, ${ }^{\mathbf{1 1}}$ the C-radical hypothesis fits very well the structure-activity relationships (SARs) found in compounds 4-7, in particular with the need of $n$-butyl groups on C3 and/or C6, which are necessary for the $\mathrm{C}$-radical generation via $\mathrm{H}$-transfer to the initially formed short-lived O-radical. In this regard, the observations that replacing all the $n$-butyl groups by methyl ${ }^{7-9}$ or propyl ${ }^{12}$ chains led to virtually inactive molecules, were especially meaningful. Moreover, the 3D-SAR study proved the active role

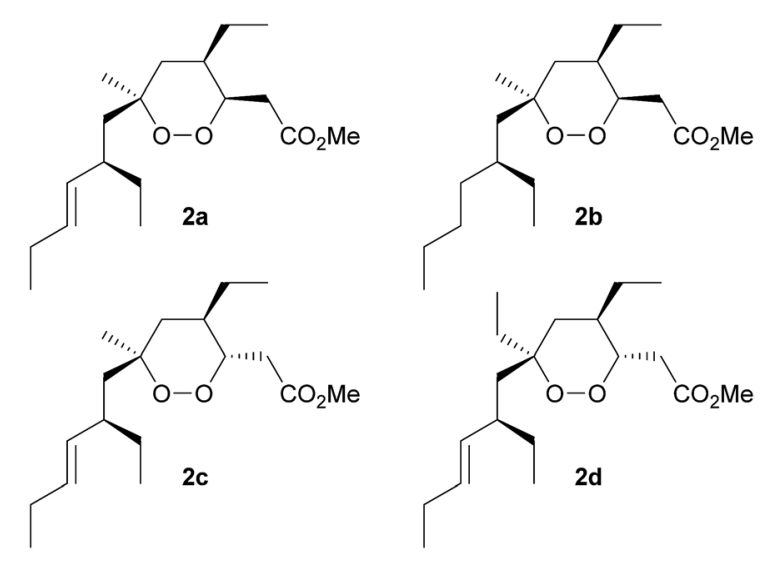

Fig. 2 Plakortin $2 \mathrm{a}$ and its congeners $2 \mathrm{~b}-\mathrm{d}$.<smiles>[R]C(=C)CC(=O)OC</smiles><smiles>[R]C1([R])CC(C(=O)OC)C([R])(O)OO1</smiles><smiles>[R]C1([R])CC(CO)C([R])(OC)OO1</smiles><smiles>[R]C1([R])COC([R])(OC)C(C(=O)OC)C1</smiles>

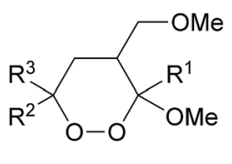

6

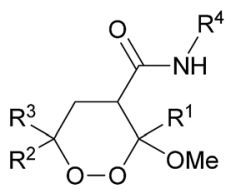

7
Scheme 1 Reagents and conditions: (a) $\mathrm{Mn}(\mathrm{OAc})_{3}(5 \mathrm{~mol} \%), \mathrm{Mn}(\mathrm{OAc})_{2}$ (5 mol\%), $\mathrm{O}_{2}$ (filled balloon), AcOH, rt, 4-12 h (70-90\%); (b) CSA (15 $\mathrm{mol} \%), \mathrm{MeOH}, 65^{\circ} \mathrm{C}, 12-24 \mathrm{~h}(75-85 \%) ;\left(\right.$ c) $\mathrm{LiBH}_{4}$ (2.8 equiv.), THF/ $\mathrm{MeOH}(10: 0.1), 0{ }^{\circ} \mathrm{C}, 4 \mathrm{~h}$ (50-90\%); (d) $\mathrm{NaH}$ (2 equiv.), Mel (2 equiv.), $\mathrm{DMF}, 0{ }^{\circ} \mathrm{C}, 4 \mathrm{~h}$ (60-90\%). (e) $i . \mathrm{NaOH} 2 \mathrm{M}$ (1.5 equiv.), $\mathrm{MeOH}, 65^{\circ} \mathrm{C}, 4-$ $12 \mathrm{~h}$; ii. $\mathrm{HCl} 1 \mathrm{M}$; iii. $\mathrm{R}^{4} \mathrm{NH}_{2}$, TBTU (1.2 equiv.), DIPEA (2 equiv.), DCM, rt, $12-16$ h $(65-85 \%)$.

of the $\mathrm{C} 4$ substituent in determining the antimalarial activity, allowing us to obtain $\mathrm{IC}_{50}$ on the chloroquine resistant (CQ-R) strain in the low micromolar range and, at the same time, very low toxicity against human cells.

In the present work, we investigate the effect on the antimalarial activity of an amine chain at $\mathrm{C} 4$ of the parent 1,2-dioxane scaffold. To this aim, a new series of compounds with general structure 9 (Fig. 3) were designed and synthesized. The original ester group of $\mathbf{4}$ has been converted into a methylamino group, which, through a flexible spacer, binds a second amino-containing scaffold or a N-heterocyclic moiety. Among the polyamine chains introduced at $\mathrm{C} 4$, the aromatic substructure of chloroquine or primaquine was included, thus leading to the generation of new endoperoxide-quinoline hybrids.

The new analogues were evaluated in vitro for antimalarial activity and cell toxicity. The resulting SARs were analyzed by using computational techniques and useful information for the

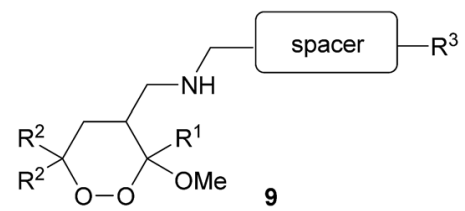

Fig. 3 General structure of 4-methylamino-1,2-dioxanes $9\left(R^{3}=\right.$ amino group containing molecular scaffold or $\mathrm{N}$-heterocyclic moiety). 
further development of this new series of antimalarials has been obtained.

\section{Results}

\subsection{Chemistry}

Investigation on our library of about 50 endoperoxides showed that compounds 4-6 possessing a cis orientation of the substituent at $\mathrm{C} 4$ and the methoxy group at C3 were more active than their 3,4-trans stereoisomers against $P f$ strains in vitro. ${ }^{9}$ Through a careful optimization study, we found conditions that yielded 3,4-cis-1,2-dioxane esters $\mathbf{4}$ as the major stereoisomer by simply stirring an isomeric mixture of hemiketals 3 in boiling methanol in the presence of camphorsulphonic acid (15 mol\%) (Scheme 1). Having in our hands an easy access to 3,4-cis esters 4, we synthesized differently substituted 3,4-cis-3-methoxy-4-methylamino derivatives 9 following the general strategy depicted in Scheme 2. To avoid unnecessary complications due to the presence of an additional stereocenter, we choose to start from esters 4 having two identical substituents $\mathrm{R}^{2}$ at $\mathrm{C6}$.

With the aim of directly reducing esters 4 to aldehydes 8 , we reacted 4 with diisobutylaluminum hydride (DIBAL) at $-78{ }^{\circ} \mathrm{C}$ in toluene/DCM, but all the conditions tested employing 1 equivalent of reducing agent, provided a $1: 1: 1$ mixture of starting ester 4, desired aldehyde 8 and overreduced alcohol 5, with the endoperoxide bond unaffected. Thus, we decided first to quantitatively reduce esters 4 to alcohols 5 using 2 equivalents of DIBAL at $-20{ }^{\circ} \mathrm{C}$, and then to oxidize 5 to 8 by using Dess-Martin periodinane. Aldehydes 8 were obtained in very good overall yield over two reductionoxidation steps, after purification by flash-chromatography on silica. The freshly prepared aldehydes were immediately used in the subsequent one-pot reductive amination reaction in methanol. Yields of the reductive amination step and chemical structures of this library of substituted amino endoperoxides 9 are reported in Table 1 (including $\mathbf{9 a - j}$,
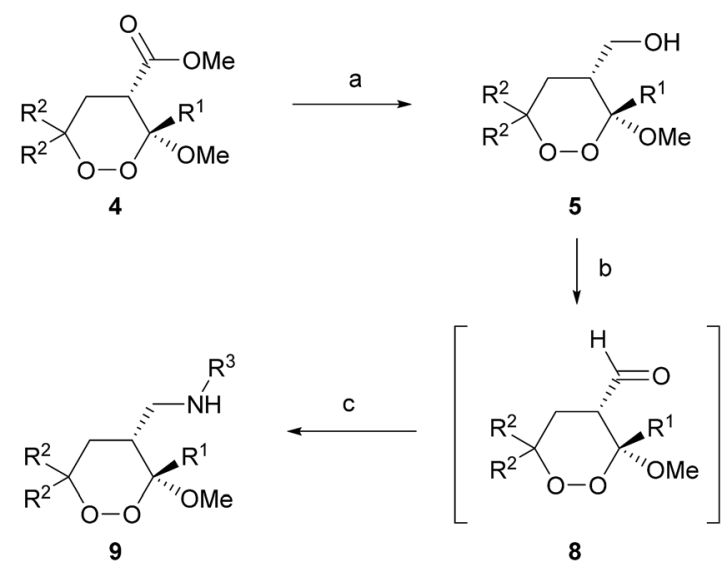

Scheme 2 Reagents and conditions: (a) DIBAL (2 equiv.), DCM, $-20{ }^{\circ} \mathrm{C}, 1 \mathrm{~h}(80-95 \%)$. (b) Dess-Martin periodinane (1.3 equiv.), DCM, rt, $1 \mathrm{~h}(80-90 \%)$. (c) i. $\mathrm{R}^{3} \mathrm{NH}_{2}$ (1 equiv.), $\mathrm{MeOH}, \mathrm{rt}, 5-7 \mathrm{~h}$; ii. $\mathrm{NaBH}_{4}(1.5$ equiv.), $\mathrm{MeOH}, 0{ }^{\circ} \mathrm{C}$ to $\mathrm{rt}, 1.5 \mathrm{~h}(80-90 \%, 2$ steps). which contain an imidazole or an aliphatic amino group) and

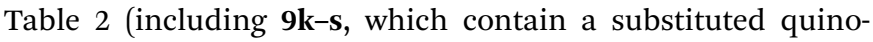
line ring).

\subsection{In vitro antimalarial activity}

The library of 3,4-cis-3-methoxy-4-aminomethyl-1,2-dioxanes 9a-s has been tested for in vitro antimalarial activity against both CQ-S (D10) and CQ-R (W2) strains, and for toxicity against a human microvascular endothelial cell line (HMEC-1). The results are summarized in Tables 1 and 2.

The imidazol-1-yl derivatives 9a-c displayed $\mathrm{IC}_{50}$ values in the high nanomolar range (200-400 $\mathrm{nM}$ ) against both parasite strains, an activity higher than the whole library of endoperoxides previously reported by us. The need of butyl chain(s) either at position $\mathrm{C} 3$ or $\mathrm{C} 6$ of the 1,2-dioxane ring, assessed to be a crucial issue in the previous series of analogues, is confirmed by the lack of activity displayed by $\mathbf{9 j}$. Moreover, the replacement of the butyl chains at C6 with a spiro cycloheptane ring (9i) decreased the antimalarial activity (Table 1). The corresponding spiro-derivatives $4 \mathbf{i}$ and $7 \mathbf{i}$ (Table 3), prepared in the course of our work on the previous series (unpublished results), owning a methyl ester and a methyl amide substituent at C4, respectively, were both completely inactive (vide infra).

A small but significant loss of antimalarial activity is associated to the replacement of the imidazole ring with simple aliphatic tertiary amines $(\mathbf{9 d} \mathbf{d}-\mathbf{h})$, particularly when the tertiary amine is included into a morpholine ring (9g). In general all the compounds reported in Table 1 are more active against CQ-R (W2) than on CQ-S (D10) strains (RI $\leq 1$; Table 1) and show variable cytotoxicity against HMEC-1, with a selectivity index (SI) ranging from 7 to $>280$. In particular, compound 9a was very safe when tested for cytotoxicity against the human cell line with SI similar to that of CQ.

The hybridization of the 1,2-dioxane scaffold with 4-amino-7chloroquinoline $(\mathbf{9 k - q})$ produced a set of compounds with significantly higher activity against both $P f$ strains and with SI values ranging from 17 to 521 (Table 2). It is noteworthy that, as in the case of the derivatives reported in Table 1, the compound that does not show any significant toxicity against HMEC-1 (9q, Table 2) is the one characterized by the lowest $c \log D$ value at physiological $\mathrm{pH}$ (vide infra).

Regarding the antimalarial activity of compounds $9 \mathbf{k}-\mathbf{q}$, although it is difficult to differentiate the role of the two pharmacophoric moieties (1,2-dioxane and chloroquine), the low $\mathrm{IC}_{50}$ values of this latest series against the CQ-S (D10) strain seem to be due to the quinoline moiety. This hypothesis is firstly corroborated by compound 9q. Indeed, possessing only methyl substituents at C3 and C6, the 1,2-dioxane moiety of 9q cannot contribute to the antimalarial activity; nevertheless, this compound is as active as CQ on CQ-S (D10) strain (Table 2). At the same time, 9q, due to its lower activity against CQ-R (W2) strain, presents an increased resistance index (RI) compared to 9k-p (Table 2). Compounds $\mathbf{9 k}-\mathbf{p}$ are indeed significantly more active than CQ against the CQ-R (W2) strain with a leveling effect of $\mathrm{IC}_{50}$ at the $100 \mathrm{nM}$ level, which could reflect the contribution of the endoperoxide pharmacophore to the 


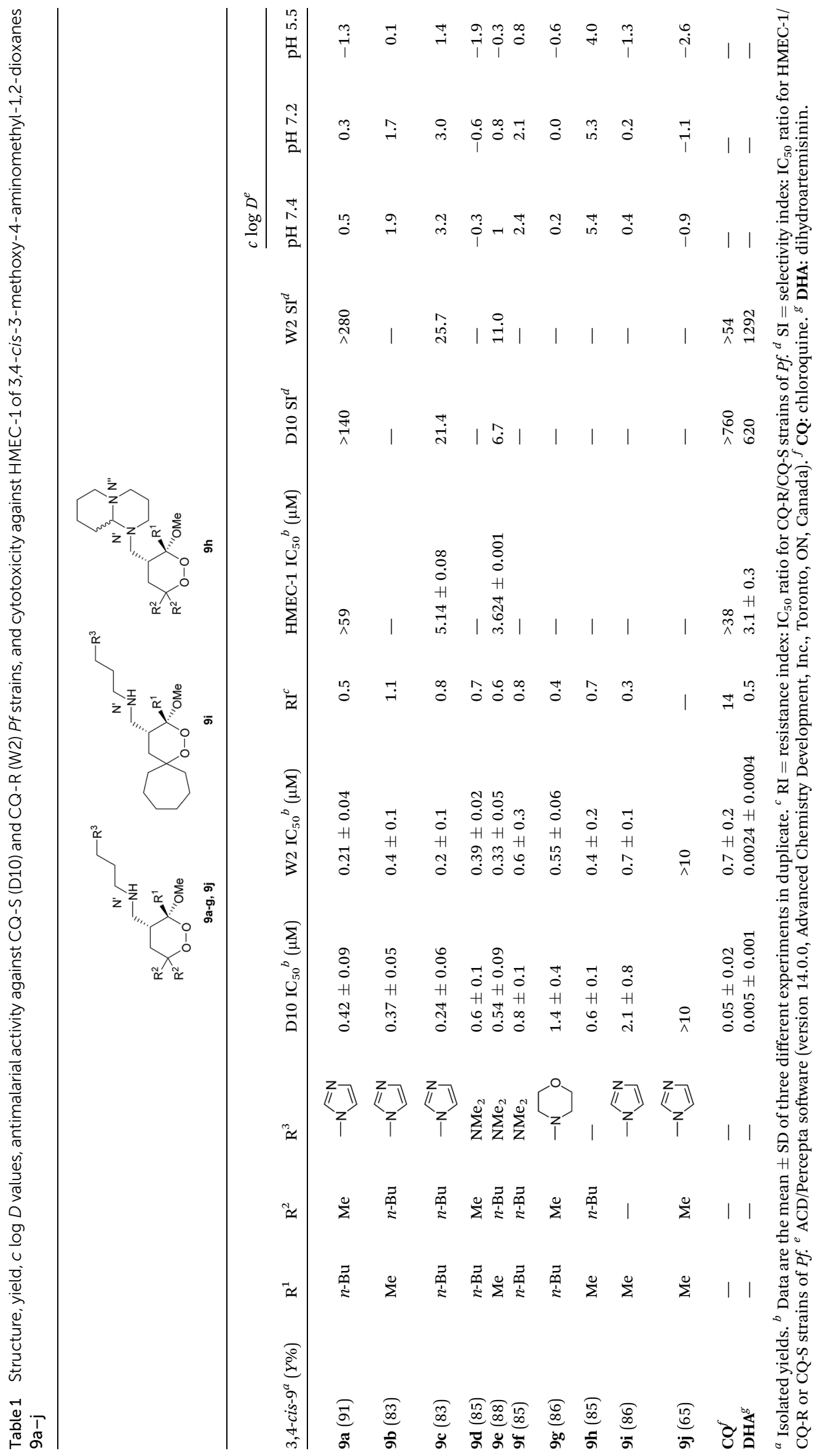


Table 2 Structure, yield, $c \log D$ values, antimalarial activity against CQ-S (D10) and CQ-R (W2) Pf strains, and cytotoxicity against HMEC-1 of 3,4-cis-3-methoxy-4-aminomethyl-1,2-dioxanes $9 \mathrm{k}-\mathrm{s}$
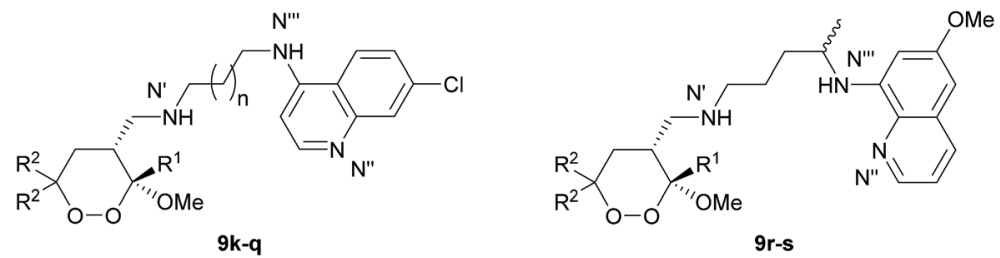

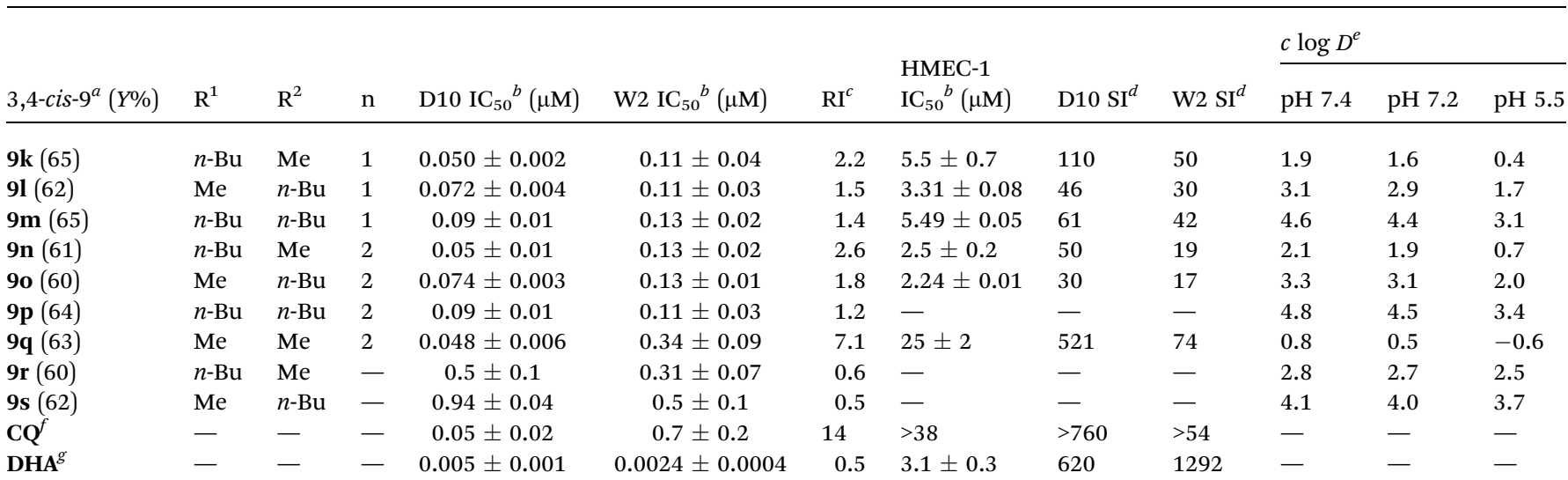

${ }^{a}$ Isolated yields. ${ }^{b}$ Data are the mean \pm SD of three different experiments in duplicate. ${ }^{c} \mathrm{RI}=$ resistance index: $\mathrm{IC}_{50}$ ratio for CQ-R/CQ-S strains of $P f$. ${ }^{d} \mathrm{SI}=$ selectivity index: $\mathrm{IC}_{50}$ ratio for HMEC-1/CQ-R or CQ-S strains of $P f .{ }^{e} \mathrm{ACD} /$ Percepta software (version 14.0.0, Advanced Chemistry Development, Inc., Toronto, ON, Canada). ${ }^{f}$ CQ: chloroquine. ${ }^{g}$ DHA: dihydroartemisinin.

Table 3 Structure, $c \log D$ values, and antimalarial activity of $4 \mathrm{i}, 7 \mathrm{i}$ and $9 \mathrm{i}$ against $C Q-S(D 10)$ and $C Q-R(W 2)$ Pf strains
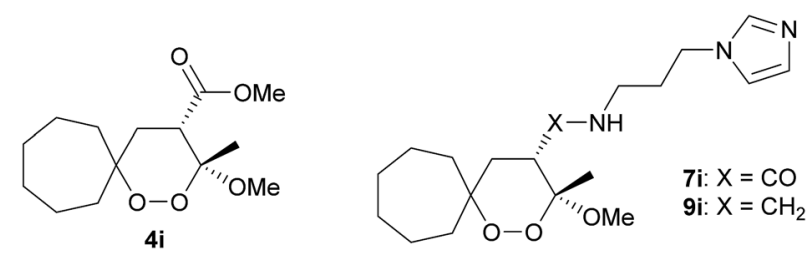

$$
c \log D^{b}
$$

\begin{tabular}{llllll} 
Compound & $\mathrm{D} 10 \mathrm{IC}_{50}{ }^{a}(\mu \mathrm{M})$ & $\mathrm{W} 2 \mathrm{IC}_{50}{ }^{a}(\mu \mathrm{M})$ & $\mathrm{pH} 7.4$ & $\mathrm{pH} 7.2$ & $\mathrm{pH} 5.5$ \\
\hline $4 \mathbf{i}$ & $>10$ & $>10$ & 3 & 3 & 3 \\
$7 \mathbf{i}$ & $>10$ & $>10$ & 2.1 & 2 & 0.6 \\
$9 \mathbf{i}$ & $2.1 \pm 0.8$ & $0.7 \pm 0.1$ & 0.4 & 0.2 & -1.3
\end{tabular}

${ }^{a}$ Data are the mean \pm SD of three different experiments in duplicate. ${ }^{b} \mathrm{ACD} /$ Percepta software (version 14.0.0, Advanced Chemistry Development, Inc., Toronto, ON, Canada).

observed antimalarial activity. Thus, a synergic and/or a resistance reverting effect of the two pharmacophores seems to occur in the case of the CQ-R (W2) strain. The 8-aminoquinoline containing hybrids $9 \mathbf{r}, \mathbf{s}$ are interesting, too, for the potential activity against the $P f$ hepatic stage and as transmission blocking agents. ${ }^{13}$ The primaquine containing hybrids 9r,s showed increased $\mathrm{IC}_{50}$ with respect to $\mathbf{9 k - p}$ (Table 2) against both CQ-R and CQ-S Pf strains.
This is in accordance with the fact that primaquine and other 8-aminoquinolines display higher activities in vivo rather than in vitro because they need a bioactivation step. ${ }^{\mathbf{1 4}}$ By consequence, the observed activity of 9r,s against both D10 and W2 strains can be mainly ascribed to the antimalarial activity of the endoperoxide moiety.

\subsection{Structure-activity relationships (SARs) studies}

All the structures reported in Tables 1 and 2 (compounds $\mathbf{9 a}-\mathbf{j}$ and $\mathbf{9 k - s}$, respectively) were subjected to computational studies in order to investigate their SARs.

The studies started with the estimation of the ionic forms present at pH 7.4 (blood), 7.2 (cytoplasm), and 5.5 (Pffood vacuole (FV)) (Table $1 \mathrm{SI} \dagger)$. Then, in order to explore the role on antimalarial activity of a possible accumulation of 1,2-dioxanes in the $\mathrm{FV}$, the distribution coefficient $(\log D)$ values at blood, cytoplasm, and FV pH, were calculated using the ACD/Percepta software (version 14.0.0, Advanced Chemistry Development, Inc., Toronto, ON, Canada). Results are reported in Tables 1 and 2.

$\log D$ is an expression of the lipophilicity of the compounds which reflects the equilibria of ionic forms at a given $\mathrm{pH}$. It is generally accepted ${ }^{\mathbf{1 5}}$ that compounds with moderate lipophilicity $(\log D 0-3)$ have a good balance between solubility and permeability and are optimal for cell membrane permeation. Thus, according to the data reported in Tables 1 and 2, although a certain degree of accumulation in the FV of the parasite is expected for all compounds, there is no clear correlation between the calculated $\log D(c \log D)$ values and the 
antimalarial activity. A similar observation has been reported for 1,2,4-trioxaquines, ${ }^{16}$ molecular hybrids containing both a quinoline and 1,2,4-trioxane pharmacophore moieties. In our case, this is true also if we exclude the quinoline-hybrids $\mathbf{9 k - \mathbf { k }}$ and we only consider the new endoperoxide derivatives $\mathbf{9 a}-\mathbf{j}$ reported in Table 1 . The $c \log D$ values do not account for the activity trend observed with the introduction of the amino chain at $\mathrm{C} 4$, such as, ((3-(1H-imidazol-3-yl)propyl)amino)methyl (9a-c) > ((3-(dimethylamino)propyl)amino)methyl (9d-f) $\approx$ (octahydro-2H-pyrido[1,2a]-pyrimidin-1-yl)methyl (9h) > ((3morpholinopropyl)amino)methyl (9g). Moreover, compound 9c, differently from $9 \mathbf{a}$ and $\mathbf{9 b}$, should be able to diffuse back to the parasite cytoplasm across the FV membrane. This property does not interfere with the antimalarial activity of $\mathbf{9 a - c}$, which is almost identical (Table 1).

To investigate the role of the $\mathrm{C} 4$ amino-imidazole chain in determining the antimalarial activity of compounds $\mathbf{9 a - c}$ (the amido-imidazole analogue of $\mathbf{9 a}$ was inactive), ${ }^{\mathbf{9}}$ compound $\mathbf{9 j}$ was synthesized. In agreement with previous SARs, ${ }^{7-9}$ its complete loss of activity confirmed that the presence of at least one butyl chain at C3 is necessary for antimalarial activity $(9 \mathbf{j} v s$. 9a, Table 1). However, due to the unfavorable $c \log D$ value at physiological pH (i.e., -0.9 , Table 1 ), the observed inactivity of 9j could in principle be ascribed to cellular pharmacokinetics. To obtain an amino-imidazole analogue with increased $c \log D$ without affecting the pharmacodynamic properties, we used the 3-methoxy-1,2-dioxaspiro[5.6]dodecane moiety. Indeed, in the ester series, the spiro derivative $4 \mathbf{i}$ resulted inactive despite its favorable $c \log D$ (Table 3), demonstrating that the spirocycloheptane substituent at C6 does not possess the pharmacodynamic requirements for antimalarial activity. Thus, we replaced the $\mathrm{C} 4$ substituent of the inactive analogues $4 \mathbf{i}$ and $7 \mathbf{i}$ with the amino-imidazole chain, through the synthesis of the analogue 9i (Table 3).

The amino-imidazole derivative $9 \mathbf{i}$ demonstrated that, when combined with a sufficient lipophilicity, just the installation of the amino-imidazole chain at $\mathrm{C} 4$ is sufficient to restore some antimalarial activity (Table 3 ). Moreover, the complete inactivity of the amido-imidazole analogue $\mathbf{7} \mathbf{i}$, proved that the restored antimalarial activity can be unambiguously ascribed to the presence of the secondary amine function. Finally, according to the data reported in Tables 1 and 2, the minimum $c \log D_{7.4}$ value for activity against HMEC- 1 appears to be +1 . Compounds 9a and 9q, characterized by a $c \log D_{7.4}$ value $<1$, are indeed devoid of any significant activity.

2.3.1 Conformational analysis and docking studies. Prevalent ionic forms at cytoplasm and $P f \mathrm{FV} \mathrm{pH}$ were subjected to an in depth conformational analysis, which included a molecular dynamics (simulated annealing, SA) procedure followed by molecular mechanics (MM) energy minimization, and the subsequent quantum mechanics (QM) full geometry optimization (MOPAC, PM7) of the resulting MM minima (see Experimental section for details). The so obtained conformers were ranked by their potential energy values and grouped into families on the basis of their 1,2-dioxane ring conformation (Table 4). It resulted that the series of derivatives 9 presents peculiar conformational parameters compared to the previous analogues 4-7 (Scheme 1).

Indeed, the presence of the amino chain at $\mathrm{C} 4$ stabilizes the Skew Boat B conformation of the 1,2-dioxane ring, which becomes by far the most populated conformer at the $\mathrm{FV} \mathrm{pH}$ (Table 4), contrarily to what observed for both plakortins ${ }^{5 c, 6}$ and the previous synthetic analogues ${ }^{7,9}$ which showed a conformational preference for the Chair A. This skew boat-like conformation of the 1,2-dioxane ring favors endoperoxide oxygens accessibility and reproduces the endoperoxide ring conformation of artemisinin (Fig. 1SI $\dagger$ ). The structural analysis of the low energy conformers (i.e., within $5 \mathrm{kcal} \mathrm{mol}^{-1}$ from the global energy minimum (GM); Tables 3SI-14SI, 21SI and 22SI $\dagger$ ), highlighted that the amino-imidazole derivatives $\mathbf{9 a - c}, \mathbf{9 j}$ and the di-amino derivatives 9d-f (Table 1), presents GM conformers showing similar conformational features, both in the protonated $\left(\mathrm{N}^{\prime}\right)$ and di-protonated $\left(\mathrm{N}^{\prime}\right.$ and $\left.\mathrm{N}^{\prime \prime}\right)$ forms. These GM conformers are characterized by the Skew Boat B conformation of the 1,2-dioxane ring and by a network of intramolecular hydrogen bonds involving $\mathrm{O} 1$ and the secondary amine $\mathrm{N}^{\prime}$ (Fig. 4, Tables 3SI-14SI, 21SI and 22SI $\dagger$ ). Moreover, they also present (with the obvious exception of $\mathbf{9 j}$ ) the intramolecular distances required for a $\mathrm{H}$-shift from a butyl chain to the putative oxygen radical, according to the pharmacophoric model resulting from our previous computational studies $^{7-9}$ (Fig. 4, 2SI and Table 2SI $\dagger$ ).

In order to further investigate the impact of this conformational behavior on antimalarial activity, we performed a dynamic docking simulation of 9c in the complex with heme. The protonation state of 9c and heme has been calculated considering the $\mathrm{pH}$ of the $\mathrm{FV}$, where heme digestion mainly occurs. ${ }^{17}$ Heme parameters and atomic partial charges were assigned using the QM method PM7. During the dynamic docking procedure, which combines Monte Carlo and SA calculations, all rotatable bonds of 9c and heme are left fully free to move. Docking studies indicated only one possible complex structure. The resulting docked complex was then subjected to a full geometry optimization by the semi-empirical QM method PM7 (Fig. 5, see Experimental section for details).

The docked conformation of 9c reproduces the key features (i.e., Skew Boat B and O1- $\mathrm{N}^{\prime}$ interaction) of the GM conformer identified by the conformational search (Fig. 4B). Moreover, in the docked complex the two protonated nitrogens $\mathrm{N}^{\prime}$ and $\mathrm{N}^{\prime \prime}$ establish charge-assisted hydrogen bonds with the ionized and neutral propionic groups of heme, respectively, similarly to what reported for the protonated amine chain of chloroquine. ${ }^{\mathbf{1 8}}$ As already mentioned, at $P f \mathrm{FV} \mathrm{pH}$, when both the basic centers are protonated, compounds $\mathbf{9 a - f}$ show a higher propensity for the Skew Boat B conformation and a hydrogen bond between $\mathrm{N}^{\prime}$ and $\mathrm{O} 1$ (Tables 4, 4SI, 6SI, 8SI, 10SI, 12SI and 14SI $\dagger$ ). In the case of compounds $9 \mathbf{a}-\mathbf{c}$, this is due to the lack of an additional electron donating group (i.e., unprotonated imidazole) competing with the endoperoxide oxygen $\mathrm{O} 1$ in establishing favorable interactions (i.e., cation- $\pi$ ) with the protonated secondary amine $\mathrm{N}^{\prime}$ (Fig. 4A vs. B, Tables 4SI, 6SI, and 8SI $\dagger$ ). In the case of compounds $9 \mathbf{d}-\mathbf{f}$, this is due to the further stabilization of the Skew Boat B conformation, caused by the 


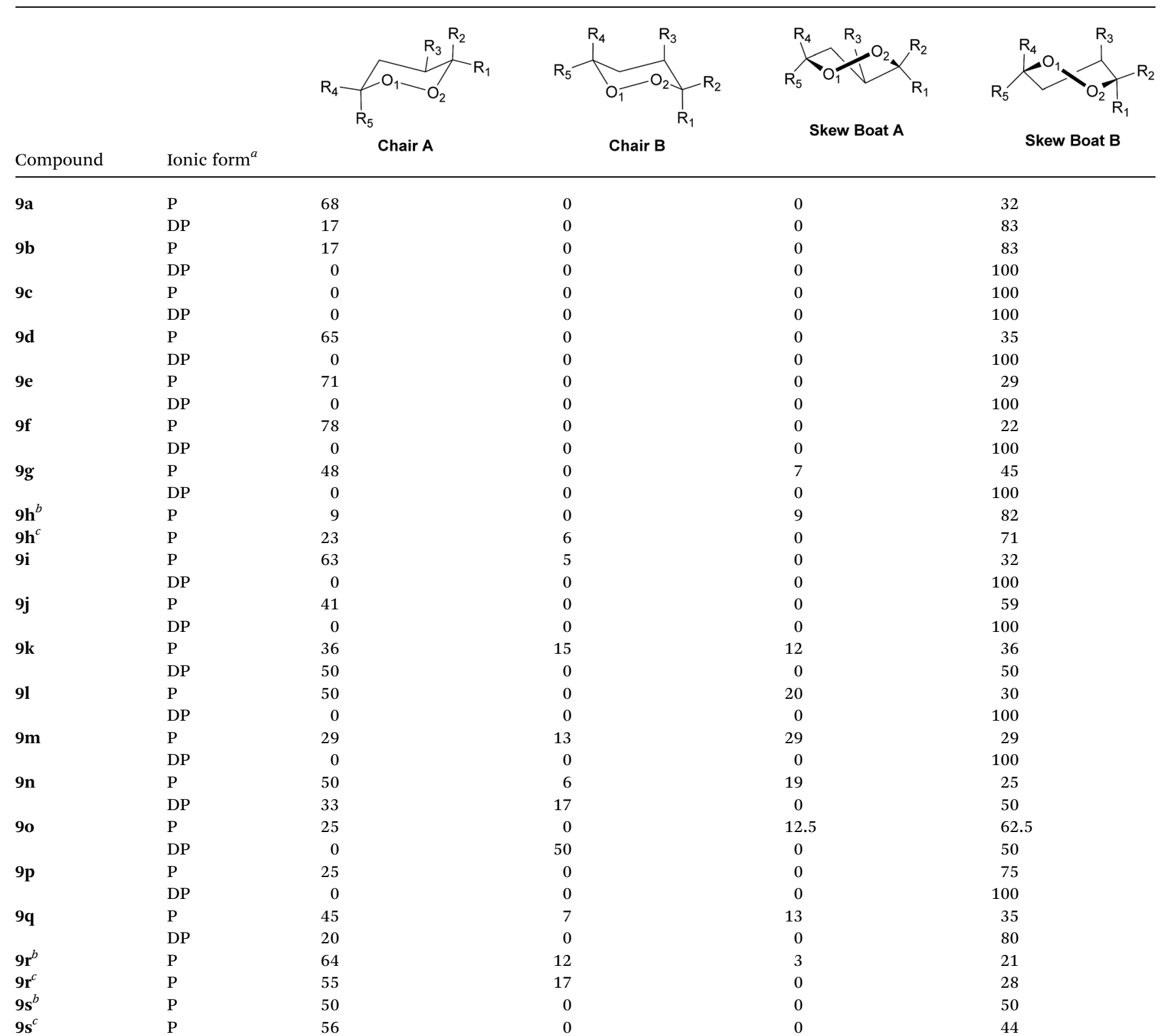

${ }^{a} \mathrm{DP}=$ di-protonated form, $\mathrm{P}=$ protonated form. ${ }^{b}$ Diastereomer with $(R)$-configured stereocenter in the side-chain. ${ }^{c}$ Diastereomer with $(S)$ configured stereocenter in the side-chain.

interaction of the distal, protonated, tertiary amine group $\left(\mathrm{N}^{\prime \prime}\right)$ with O1, O2, and O7 (Fig. 4A vs. C, Tables 10SI, 12SI and 14SI†). By consequence, the only difference between the aminoimidazole (9a-c) and the di-amino (9d-f) derivatives is that, in the di-protonated form, the GM conformers of the former adopt an extended conformation of the substituent at $\mathrm{C} 4$, with the protonated imidazole ring pointing away from the rest of the molecule. Thus, the GM conformers of $\mathbf{9 a}-\mathbf{c}$ correspond to the heme interacting conformation resulting from docking calculations (Fig. 4 vs. 5). On the contrary, in the GM conformers of 9d-f the protonated tertiary amine $\mathrm{N}^{\prime \prime}$ is hydrogen bonded to O1, O2, and $\mathrm{O} 7$ (Fig. 4C vs. B). Accordingly, when the di-amino derivatives 9d-f approach heme, the distal protonated amine $\mathrm{N}^{\prime \prime}$ should firstly release the intramolecular hydrogen bonds to then establish ionic interactions with the propionate groups of heme. This could account for the overall higher antimalarial activity of 9a-c with respect to $9 \mathbf{d}-\mathbf{f}$ (Table 1 ).

According to the calculated apparent $\mathrm{p} K_{\mathrm{a}}$ values (Table $1 \mathrm{SI} \dagger$ ), unlike compounds $\mathbf{9 a - f , ~ t h e ~ s i g n i f i c a n t l y ~ l e s s ~ a c t i v e ~ m o r p h o l i n e ~}$ analogue $\mathbf{9 g}$ is still (44\%) mono-protonated at the acidic FV pH. In this form, the GM conformer of $\mathbf{9 g}$ does not present the Skew Boat $\mathrm{B}$ conformation and the $\mathrm{O} 1-\mathrm{N}^{\prime}$ interaction, and the first conformer with these features is at $\approx 1 \mathrm{kcal} \mathrm{mol}^{-1}$ from the GM (Table 15SI $\dagger$ ). On the other hand, in the di-protonated form, $\mathbf{9 g}$ 
A

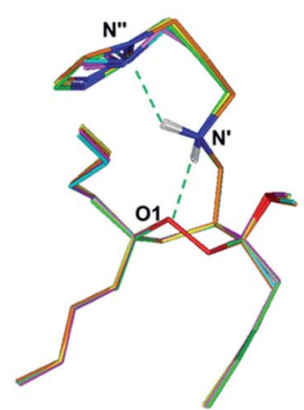

B

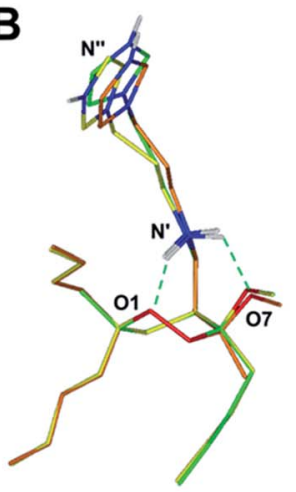

C

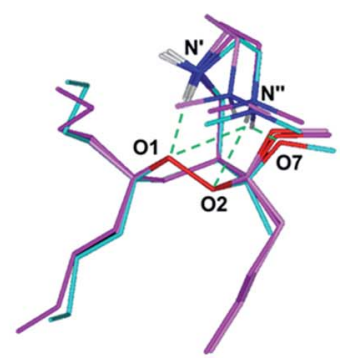

Fig. 4 Superimposition of GM conformers of: (A) 9a (green), 9b (orange), 9c (yellow), 9d (pink), 9e (cyan), and 9f (magenta); all protonated on N'; (B) 9a (green), 9b (orange), and 9c (yellow); protonated on $\mathrm{N}^{\prime}$ and $\mathrm{N}^{\prime \prime}$; (C) 9d (pink), 9e (cyan), and 9f (magenta); protonated on $\mathrm{N}^{\prime}$ and $\mathrm{N}^{\prime \prime}$. The molecules are colored by atom type $(\mathrm{O}=$ red, $\mathrm{N}=$ blue, and $\mathrm{H}=$ white). Hydrogens are omitted for sake of clarity, with the exception of those involved in hydrogen bonds (highlighted by a green dashed line).

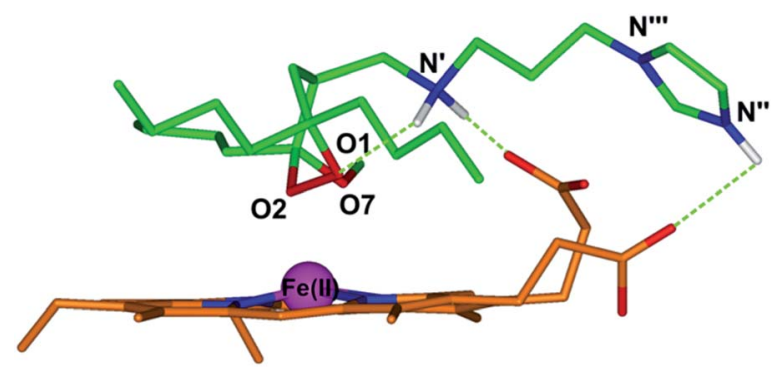

Fig. 5 Docking results of $9 c$ (green; protonated on $\mathrm{N}^{\prime}$ and $\mathrm{N}^{\prime \prime}$ ) in complex with heme (orange) optimized by the semi-empirical QM method PM7. The molecules are colored by atom type $(\mathrm{O}=$ red; $\mathrm{N}=$ blue; $\mathrm{Fe}=$ magenta and $\mathrm{H}=$ white). Iron atom vdW volume is shown (scaled by $70 \%$ for clarity of presentation). Hydrogens are omitted for sake of clarity, with the exception of those involved in hydrogen bonds (highlighted by a green dashed line).

behaves similarly to 9d-f (Fig. 4C), i.e., with the protonated tertiary amine $\left(\mathrm{N}^{\prime \prime}\right)$ establishing hydrogen bonds with O7 (Table 16SI $\dagger$ ).

Thus, also in the case of di-protonated $\mathbf{9 g}$, the morpholine nitrogen could establish an extra-interaction with heme propionate groups only after losing its intramolecular H-bond.

A peculiar case is represented by compound $9 \mathbf{h}\left(\mathrm{W} 2 \mathrm{IC}_{50}=\right.$ $400 \mathrm{nM}$, Table 1), evaluated as a mixture of two diastereomers differing for the configuration at the stereogenic carbon of the bicyclic ring.

In this analogue the two equally basic nitrogens (single $\mathrm{p} K_{\mathrm{a} 1}$ : $7.56 \pm 0.20$ and single $\mathrm{p} K_{\mathrm{a} 2}: 7.24 \pm 0.20$ ) are constrained into a bicyclic structure and, according to the calculated apparent $\mathrm{p} K_{\mathrm{a}}$ value, only the mono-protonated form is present at both cytoplasm and FV pHs (Table $1 \mathrm{SI} \dagger$ ). In order to investigate the role of the bicyclic ring on the antimalarial activity, $9 \mathbf{h}$ diastereomers were subjected to the same docking procedure applied to 9c (see Experimental section for details). Also in this case, the docking studies indicated only one possible complex structure for each 9h diastereomer. According to the conformational analysis results (Tables $17 \mathrm{SI}$ and $18 \mathrm{SI} \dagger$ ), although not showing the hydrogen bond between $\mathrm{N}^{\prime}$ and $\mathrm{O} 1$, the bioactive conformers of the two diastereomers still presented the Skew Boat $\mathrm{B}$ conformation of the 1,2-dioxane ring with the two conformationally constrained amine nitrogens correctly positioned to interact with the negatively charged heme propionate group (Fig. 3SI $\dagger$ ).

Finally, the amino-imidazole spiro derivative $9 \mathbf{i}$ (Table 1), is again present in the di-protonated form at FV pH (Table $1 \mathrm{SI}_{\dagger} \dagger$ ). The GM conformer of this form presents both the Skew Boat B and the $\mathrm{O} 1-\mathrm{N}^{\prime}$ interaction (Table 20SI $\dagger$ ), but, according to experimental peroxide oxygen-heme iron distances taken from the Cambridge Crystallographic Structural Data Bank, ${ }^{19}$ the presence of the rigid spirocycloheptane at C6 impairs the endoperoxide approach to heme iron (Fig. 4SI†).

The conformational behavior of the endoperoxide-aminoquinoline hybrids 9k-s (Table 2) was evaluated by applying the same computational protocol used for $\mathbf{9 a}-\mathbf{j}$. The presence of the bulky quinoline moiety determined a less homogenous conformational behavior of the low energy conformers of $\mathbf{9 k - s}$. Indeed, due to the hydrophobic interaction between the quinoline system and the butyl chain(s), the conformational preference is also affected by the substitution at C6 (Tables 4 and 23SI-40SI $\dagger$ ). Nevertheless, the GM conformers of compounds $9 \mathbf{k}-\mathbf{s}$ are still characterized by the Skew Boat B, both, in the mono- and di-protonated forms (Tables 23SI40SI $\dagger$ ).

The endoperoxide-7-chloroquinoline hybrids $\mathbf{9 k - \mathbf { q }}$ (Table 2) are entirely present in the di-protonated form at $\mathrm{FV} \mathrm{pH}$, while they are mostly $(\approx 80 \%)$ mono-protonated at cytoplasm $\mathrm{pH}$ (Table $1 \mathrm{SI} \dagger$ ). Considering the mono-protonated form, $\mathrm{N}^{\prime}$ is hydrogen bonded to $\mathrm{O} 1$ and $\mathrm{O} 7 \mathrm{in}$ 9k, 9n, and 9q (Fig. 6A), and only to $\mathrm{O} 1$ in 91, 9m, 9o, and 9p (Fig. 6B). On the other hand, in the di-protonated form $\mathrm{N}^{\prime}$ is hydrogen bonded to $\mathrm{O} 1(\mathbf{9 k - m})$ or to $\mathrm{O} 7(\mathbf{9 n - q})$, while $\mathrm{N}^{\prime \prime \prime}$ always interacts with $\mathrm{O} 1, \mathrm{O} 2$, and $\mathrm{O} 7$ (Fig. 6C).

Thus, the exact pattern of intramolecular hydrogen bonds is determined by the presence of the butyl chains at C6 in the protonated forms (Fig. 6A and B), and by the length of the alkyl 
A

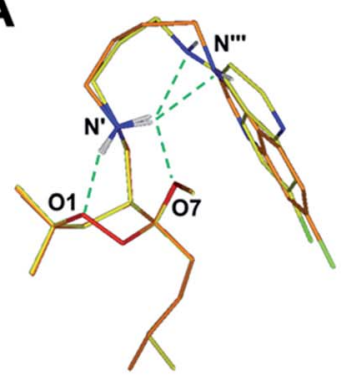

B

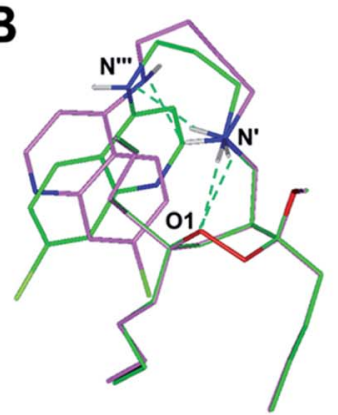

C

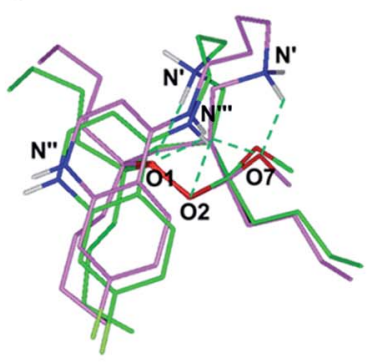

Fig. 6 Superimposition of the GM conformers of: (A) 9k (yellow) and 9n, 9q (orange) (protonated on $\mathrm{N}^{\prime}$ ); (B) 9l, 9m (green) and 9o, 9p (pink) (protonated on $\mathrm{N}^{\prime}$ ); (C) $9 \mathrm{k}-\mathrm{m}$ (green) and $9 \mathrm{n}-\mathrm{q}$ (pink) (protonated on $\mathrm{N}^{\prime}$ and $\left.\mathrm{N}^{\prime \prime}\right)$. The molecules are colored by atom type $(\mathrm{O}=$ red, $\mathrm{N}=$ blue, and $\mathrm{H}=$ white). Hydrogens are omitted for sake of clarity, with the exception of those involved in hydrogen bonds (highlighted by a green dashed line).
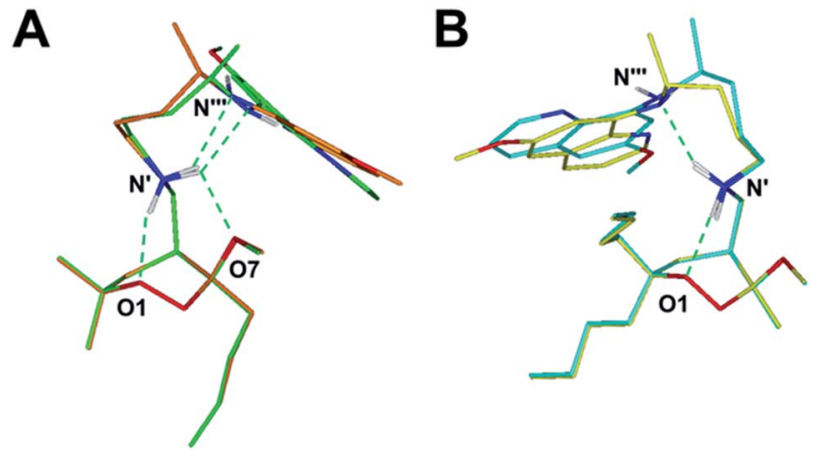

Fig. 7 Superimposition of GM conformers of: (A) $9 r$ diastereomer (green) with $(R)$-configured stereocenter in the side-chain and diastereomer (orange) with (S)-configured stereocenter in the side-chain; (B) $9 \mathrm{~s}$ diastereomer (yellow) with (R)-configured stereocenter in the side-chain and diastereomer (cyan) with $(S)$-configured stereocenter in the side-chain. The molecules are colored by atom type $(\mathrm{O}=\mathrm{red}, \mathrm{N}$ $=$ blue, and $\mathrm{H}=$ white). Hydrogens are omitted for sake of clarity, with the exception of those involved in hydrogen bonds (highlighted by a green dashed line).

chain connecting the two protonated amino groups in the diprotonated forms (Fig. 6C).

It has to be underlined that, anyway, the GM conformers of 9k-q show the quinoline nitrogen $\left(\mathrm{N}^{\prime \prime}\right)$ accessible to heme iron interaction, while the endoperoxide function is sterically hindered by the quinoline ring (Fig. 6).

The primaquine-type hybrids $9 \mathbf{r}$ and $9 \mathrm{~s}$ are only present in the mono-protonated form at, both, $\mathrm{FV}$ and cytoplasm $\mathrm{pH}$ (Table 1SI $\dagger$ ), and, as observed for the mono-protonated GM conformers of $\mathbf{9 k - q}, \mathrm{N}^{\prime}$ is hydrogen bonded to $\mathrm{O} 1$, or to $\mathrm{O} 1$ and O7, depending on the presence of the butyl chains at C6 (Fig. 7). Contrarily to $\mathbf{9 k - q}$, in hybrids $\mathbf{9 r}-\mathbf{s}$ the quinoline ring does not hinder the endoperoxide group (Fig. 6A and B vs. 7A and B).

\section{Discussion}

We analyzed the SARs of our new compounds considering the possible roles of the amine chain at $\mathrm{C} 4$ on the antimalarial

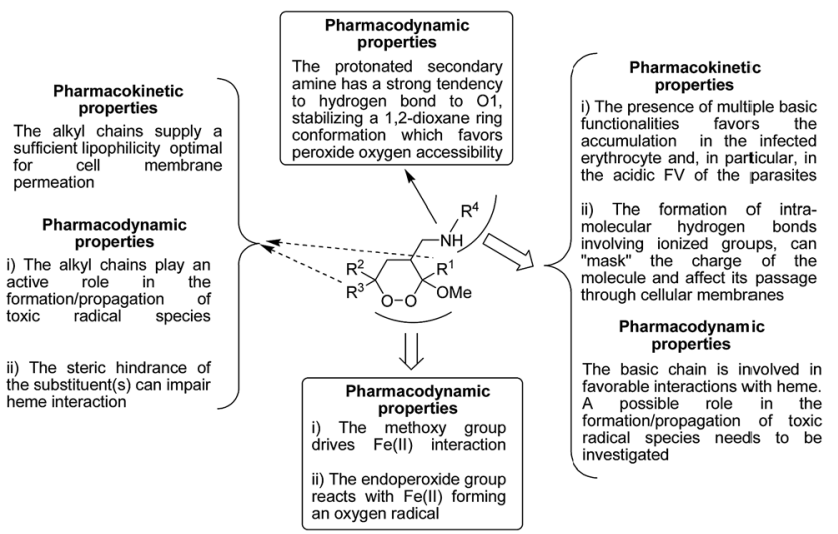

Fig. 8 Schematic representation of the SARs of the 4-methylamino1,2-dioxanes 9a-s.

activity according to our previously developed pharmacophore model. ${ }^{5 c-9}$ Obtained results are summarized in Fig. 8.

Several amines are known either to be active themselves as antimalarials $^{20}$ or to be present as additional, favorable, pharmacophoric features (i.e., bioactive substructure) in a variety of molecular scaffolds already exhibiting antimalarial activity. ${ }^{21}$ This is the case of the new series of endoperoxides 9a-s, which show an enhanced antimalarial activity compared to the parent compounds $4-7$, thanks to the amine substituent at C4. This improvement in the activity can be ascribed to cellular pharmacokinetics and/or pharmacodynamics. Polyamines are known to play a crucial role as radical scavengers in biological environments ${ }^{22}$ and their ability to shuttle a freeradical from oxygen to carbon atoms has been broadly investigated. ${ }^{23}$ Accordingly, the polyamine substituent could increase the activity of molecular scaffolds whose activity is strictly related to their redox potential by playing an active role in the formation/propagation of toxic radical species. In addition, for compounds supposed to interact with free heme, a basic chain could be involved in favorable interactions with heme propionate groups. At this regard, the conformational analysis performed on members of the series 9 revealed a strong tendency of the protonated secondary amine to form a 
hydrogen bond with O1, stabilizing a 1,2-dioxane ring conformation which favors peroxide oxygen accessibility. This was confirmed by docking calculation of 9c in complex with heme, which also highlighted favorable interactions between the polyamine chain and the heme propionate groups, in agreement to what observed in the recently crystallized metalloporphyrin $\mu$-oxo dimer in complex with chloroquine. ${ }^{18}$ Given the formation of this pre-reactive complex, a possible scenario is that, after the Fe(II) catalyzed generation of the distonic radical anion, the secondary amine could simultaneously protonate the oxygen anion and shuttle the oxygen radical to an adjacent carbon via a $\mathrm{H}$ radical shift. ${ }^{23}$

In addition, the presence of multiple basic functionalities may favor the accumulation of compounds $\mathbf{9 a - s}$ in the infected erythrocyte and, in particular, in the acidic FV of the parasites. More than be achieved through a polyamine transporter, ${ }^{24}$ most likely this could be due to an impairing of the back diffusion across the membrane of a single, or better a double, protonated derivative. Calculated $\mathrm{p} K_{\mathrm{a}}$ and $\log D$ values at cytoplasm and FV $\mathrm{pH}$ pointed out that compounds 9a-s can accumulate in the parasite $\mathrm{FV}$, but no linear relation was observed between the antimalarial activity and the $c \log D$ values, indicating that other parameters also affect the antimalarial activity. It is noteworthy that most of the low energy conformers (i.e., within $5 \mathrm{kcal} \mathrm{mol}^{-1}$ from the GM) of compounds 9a-s present an intramolecular hydrogen bond between the two amine functions. As already observed by us and others, ${ }^{25}$ the formation of intramolecular hydrogen bonds involving ionized groups, can "mask" the charge of the molecule and affect its passage through cellular membranes. In particular, the formation of an intramolecular hydrogen bond between the exocyclic quinoline nitrogen and the alkyl chain amino group of ferroquine has been proven to enhance its passage across the cell membrane. ${ }^{25 a}$ Such conformational effects cannot be properly taken into account by the predictive algorithm $^{30}$ used to calculate the $\log D$ values.

The subgroup of 1,2-dioxanes 9k-s hybridizes two biologically active entities, the 1,2-dioxane scaffold and a quinolinebased pharmacophore. Over the last ten years examples of artemisinin-quinolines hybrids have been reported. ${ }^{26} \mathrm{~A}$ recent survey shows the most interesting results obtained with hybrid molecules containing fully synthetic 1,2,4-trioxanes or 1,2,4trioxolanes and an aminoquinoline derivative. ${ }^{27}$ These hybrid molecules display a dual mode of action, a concept referred to as "covalent bitherapy", thus they promote heme alkylation with the peroxy entity, and heme stacking with the aminoquinoline moiety resulting in a reinforced inhibition of haemozoin formation. ${ }^{28}$ Targeting the parasite by two distinct mechanisms has also the advantage of delaying or circumventing the development of resistance. ${ }^{29}$

In the case of the hybrids $\mathbf{9 k - p}$, the higher activity of chloroquine with respect to the peroxide moiety likely plays a major role in the antimalarial activity against CQ-S strains. On the contrary, 9k-p are more active than chloroquine against CQ-R strains and resulting SARs suggest that the peroxide pharmacophore is responsible for the observed antimalarial activity. It cannot be excluded that the increased activity against CQ-R strains is attributable to the modification of the basic side chain of chloroquine, which would not to be recognized by the mutated CQ-transporter.

Contrarily to chloroquine, primaquine is known to be poorly active in vitro against $P f$ infected erythrocytes, both on CQ-S and CQ-R strains $\left(\mathrm{W} 2 \mathrm{IC}_{50}=3.3 \mu \mathrm{M}\right) .{ }^{26 a}$ By consequence, the significant antimalarial activity displayed by the hybrids 9r and 9s has to be attributed to the mechanism of action of the peroxide moiety, while the primaquine moiety behaves, in this case, just as an amine-containing C4 substituent.

In summary, optimization of the cellular pharmacokinetics of our antimalarial peroxides through the introduction of an amino side chain at $\mathrm{C} 4$, seems not to be the only factor responsible for their increased antimalarial activity. Indeed, according to the developed pharmacophore model for plakortin and its synthetic analogues, ${ }^{5 c-9}$ the substituent at C4 could also play a pharmacodynamic role by affecting the ability of the peroxide bridge to undergo reductive cleavage and to generate/propagate the putative toxic radical chain. Molecular modeling studies suggest that the increased antimalarial activity is related to the stabilization of a conformation which favors the hypothesized reductive cleavage of the endoperoxide bridge with a possible involvement of the introduced amine functions in putative toxic radical formation/propagation. This is supported by the fact that replacing the amide group with an amino group not only increased the antimalarial activity of the whole series but also determined different SARs. Indeed, the amido-imidazole analogue of 9a (one butyl chain at C3, W2 (CQ-R) strain: $\left.\mathrm{IC}_{50}=0.21 \mu \mathrm{M}\right)$ was inactive as antimalarial, while the amidoimidazole analogue of $\mathbf{9 b}$ (two butyl chain at C6, W2 (CQ-R) strain: $\mathrm{IC}_{50}=0.4 \mu \mathrm{M}$ ) was one of our most active derivatives (W2 (CQ-R) strain: $\left.\mathrm{IC}_{50}=0.5 \mu \mathrm{M}\right){ }^{9}$ Thus, replacing the amide group with an amino group increased the antimalarial activity independently from the position of the butyl chain(s). Although the inactivity of $\mathbf{9 j}$ demonstrated the need of at least one butyl chain at C3 (9j vs. 9c), the activity of $9 \mathbf{i}$ compared to $7 \mathbf{i}$ and $\mathbf{4 i}$ indicated that the secondary amine function at $\mathrm{C} 4$ is sufficient to restore some antimalarial activity and that the inactivity of $\mathbf{9 j}$ is likely due to its unfavorable $\log D$. At this regard, it is worth of note, that, according to our $c \log D_{7.4}$ values, the minimum lipophilic threshold to be active against infected erythrocytes and normal human cells is $\sim-1$ and $\sim+1$, respectively. By consequence, compound $9 \mathbf{9 a}$, with $c \log D_{7.4}=0.5$, shows an $\mathrm{IC}_{50}$ of $210 \mathrm{nM}$ on W2 (CQ-R) strain and no activity on HMEC-1 cells, presenting an optimal SI.

\section{Conclusions}

The inclusion of a substituted amine moiety on our easily accessible 3-methoxy-1,2-dioxane scaffold led to a significant improvement of the antimalarial activity as a result of a combination of pharmacokinetic and pharmacodynamic effects that, rationalized in the light of our pharmacophoric model, can steer the development of further optimized 1,2-dioxane antimalarials. 


\section{Experimental Sections}

\subsection{General experimental procedures}

Low and high resolution ESI-MS spectra were registered on a LTQ OrbitrapXL (Thermo Scientific) mass spectrometer. ${ }^{1} \mathrm{H}(400$ $\mathrm{MHz})$ and ${ }^{13} \mathrm{C}(100 \mathrm{MHz}) \mathrm{NMR}$ spectra were measured on a Varian INOVA spectrometer. Chemical shifts were referenced to the residual solvent signal $\left(\mathrm{CDCl}_{3}: \delta_{\mathrm{H}} 7.26, \delta_{\mathrm{C}} 77.0\right)$. A Knauer HPLC apparatus equipped with refraction index detector was used to purify and assess purity ( $>95 \%$ ) of all final products. LUNA (normal phase) (Phenomenex) columns were used, with elution with EtOAc/ $n$-hexane mixtures and $0.7 \mathrm{ml} \mathrm{min}^{-1}$ as flow rate.

\subsection{Synthesis}

5.2.1 General procedure for the preparation of compounds 9. A 1 M DIBAL solution in toluene ( 2 equiv.) was added dropwise at $-20{ }^{\circ} \mathrm{C}$ to a solution of the 1,2-dioxane ester 4 in anhydrous $\mathrm{CH}_{2} \mathrm{Cl}_{2}$, under inert atmosphere. The reaction was stirred for $1 \mathrm{~h}$ at the same temperature and quenched by addition of a saturated aqueous solution of sodium potassium tartrate. The biphasic system was stirred overnight until two separate layers were formed. The aqueous phase was extracted with $\mathrm{CH}_{2} \mathrm{Cl}_{2}$, the combined organic phases were dried over $\mathrm{Na}_{2} \mathrm{SO}_{4}$ and evaporated under reduced pressure. The intermediate 4-hydroxymethyl-1,2-dioxanes $\mathbf{5}$ were purified by flashchromatography on silica gel, eluting with cyclohexane/ethyl acetate mixtures. The spectral data and physical properties of compounds 5 were identical to the ones previously reported. ${ }^{8}$ Alcohol 5 was dissolved in $\mathrm{CH}_{2} \mathrm{Cl}_{2}$ and further treated with Dess-Martin periodinane (1.3 equiv.) under inert atmosphere for $1 \mathrm{~h}$ at room temperature. The reaction was quenched with a saturated aqueous solution of sodium thiosulphate and the organic solvent was removed under reduced pressure. The aqueous phase was extracted with AcOEt, the combined organic phases were dried over $\mathrm{Na}_{2} \mathrm{SO}_{4}$ and evaporated under reduced pressure. Aldehydes $\mathbf{8}$ were purified by flash-chromatography on silica gel, eluting with cyclohexane/ethyl acetate mixtures and immediately used in the subsequent step. Aldehydes 8 were then dissolved in dry $\mathrm{MeOH}$ under inert atmosphere and the desired amine component was added ( 1 equiv.). The reaction was stirred at room temperature for 5-7 $\mathrm{h}$, until no starting material was detected by TLC. The solution was cooled to $0{ }^{\circ} \mathrm{C}$ and $\mathrm{NaBH}_{4}$ (1.5 equiv.) was added under inert atmosphere. The reaction mixture was further stirred at room temperature for 1.5 $h$ and quenched with $\mathrm{H}_{2} \mathrm{O}$. The organic solvent was removed under reduced pressure and the aqueous phase was extracted with AcOEt. The combined organic phases were dried over $\mathrm{Na}_{2} \mathrm{SO}_{4}$ and evaporated under reduced pressure. The desired 4aminomethyl-1,2-dioxanes 9 were obtained pure after purification by flash-chromatography on silica gel, eluting with $\mathrm{CH}_{2} \mathrm{Cl}_{2}$ / $\mathrm{MeOH}$ mixtures. The yields of the single reactions have been reported in Tables 1 and 2 .

Compound 9a. ESIMS: $m / z 340[\mathrm{M}+\mathrm{H}]^{+}$. HREIMS: $m / z$ 340.2604, calcd. for $\mathrm{C}_{18} \mathrm{H}_{34} \mathrm{~N}_{3} \mathrm{O}_{3} \mathrm{~m} / \mathrm{z}$ 340.2600. ${ }^{1} \mathrm{H}$ NMR (400 $\left.\mathrm{MHz} \mathrm{CDCl}_{3}\right) \delta=7.46(\mathrm{~s}, 1 \mathrm{H}), 7.05(\mathrm{~s}, 1 \mathrm{H}), 6.91(\mathrm{~s}, 1 \mathrm{H}), 4.03(\mathrm{t}, J$ $=6.9 \mathrm{~Hz}, 2 \mathrm{H}), 3.28(\mathrm{~s}, 3 \mathrm{H}), 2.68(\mathrm{dd}, J=11.9,4.1 \mathrm{~Hz}, 1 \mathrm{H}), 2.56(\mathrm{t}$,
$J=6.7 \mathrm{~Hz}, 2 \mathrm{H}), 2.49(\mathrm{dd}, J=11.9,8.0 \mathrm{~Hz}, 1 \mathrm{H}), 2.17(\mathrm{ddt}, J=12.5$, 8.5, $4.4 \mathrm{~Hz}, 1 \mathrm{H}), 1.92(\mathrm{p}, J=6.8 \mathrm{~Hz}, 2 \mathrm{H}), 1.80-1.68$ (m, 3H), 1.69$1.57(\mathrm{~m}, 1 \mathrm{H}), 1.53$ (dd, $J=12.9,4.7 \mathrm{~Hz}, 1 \mathrm{H}), 1.36(\mathrm{~s}, 3 \mathrm{H}), 1.36-$ $1.26(\mathrm{~m}, 4 \mathrm{H}), 1.17(\mathrm{~s}, 3 \mathrm{H}), 0.90(\mathrm{t}, J=6.9 \mathrm{~Hz}, 3 \mathrm{H}) .{ }^{13} \mathrm{C} \mathrm{NMR}(100$ $\left.\mathrm{MHz}, \mathrm{CDCl}_{3}\right) \delta=137.5,129.8,119.2,104.9$, 78.3, 50.5, 49.0, 47.0, 45.0, 35.3, 35.2, 32.2, 31.2, 27.8, 26.6, 23.6, 23.1, 14.3.

Compound 9b. ESIMS: $m / z$ 382 $[\mathrm{M}+\mathrm{H}]^{+}$. HREIMS: $m / z$ 382.3077, calcd. for $\mathrm{C}_{21} \mathrm{H}_{40} \mathrm{~N}_{3} \mathrm{O}_{3} \mathrm{~m} / \mathrm{z}$ 382.3070. ${ }^{1} \mathrm{H}$ NMR (400 $\left.\mathrm{MHz}, \mathrm{CDCl}_{3}\right) \delta=7.48(\mathrm{~s}, 1 \mathrm{H}), 7.05(\mathrm{~s}, 1 \mathrm{H}), 6.91(\mathrm{~s}, 1 \mathrm{H}), 4.04(\mathrm{t}, J$ $=6.9 \mathrm{~Hz}, 2 \mathrm{H}), 3.29(\mathrm{~s}, 3 \mathrm{H}), 2.74(\mathrm{dd}, J=12.0,4.1 \mathrm{~Hz}, 1 \mathrm{H}), 2.58(\mathrm{t}$, $J=6.7 \mathrm{~Hz}, 2 \mathrm{H}), 2.51(\mathrm{dd}, J=11.9,7.9 \mathrm{~Hz}, 1 \mathrm{H}), 2.00-1.82(\mathrm{~m}, 4 \mathrm{H})$, $1.65(\mathrm{t}, J=12.7 \mathrm{~Hz}, 1 \mathrm{H}), 1.55(\mathrm{dd}, J=12.8,4.7 \mathrm{~Hz}, 1 \mathrm{H}), 1.51-1.40$ (m, 2H), 1.40-1.31 (m, 4H), $1.29(\mathrm{~s}, 3 \mathrm{H}), 1.29-1.15(\mathrm{~m}, 6 \mathrm{H}), 0.92$ $(\mathrm{t}, J=7.1 \mathrm{~Hz}, 3 \mathrm{H}), 0.90(\mathrm{t}, J=6.9 \mathrm{~Hz}, 3 \mathrm{H}) .{ }^{13} \mathrm{C} \mathrm{NMR}(100 \mathrm{MHz}$, $\left.\mathrm{CDCl}_{3}\right) \delta=137.2,129.4,118.9,102.1,81.9,50.6,48.7,46.5,44.6$, 39.0, 36.3, 32.2, 31.5, 30.6, 25.5, 24.9, 23.2, 23.2, 19.0, 14.1, 14.0.

Compound 9c. ESIMS: $m / z$ 424 $[\mathrm{M}+\mathrm{H}]^{+}$. HREIMS: $m / z$ 424.3542, calcd. for $\mathrm{C}_{24} \mathrm{H}_{46} \mathrm{~N}_{3} \mathrm{O}_{3} \mathrm{~m} / \mathrm{z}$ 424.3539. ${ }^{1} \mathrm{H}$ NMR (400 $\left.\mathrm{MHz}, \mathrm{CDCl}_{3}\right) \delta=7.47(\mathrm{~s}, 1 \mathrm{H}), 7.05(\mathrm{~s}, 1 \mathrm{H}), 6.91(\mathrm{~s}, 1 \mathrm{H}), 4.04(\mathrm{t}, J$ $=6.9 \mathrm{~Hz}, 2 \mathrm{H}), 3.28(\mathrm{~s}, 3 \mathrm{H}), 2.69(\mathrm{dd}, J=11.8,4.0 \mathrm{~Hz}, 1 \mathrm{H}), 2.56(\mathrm{t}$, $J=6.8 \mathrm{~Hz}, 2 \mathrm{H}), 2.49(\mathrm{dd}, J=12.0,7.9 \mathrm{~Hz}, 1 \mathrm{H}), 2.16(\mathrm{td}, J=7.6$, $3.8 \mathrm{~Hz}, 1 \mathrm{H}), 1.99-1.80(\mathrm{~m}, 3 \mathrm{H}), 1.78-1.59$ (m, 4H), 1.55 (dd, $J=$ 13.0, $4.8 \mathrm{~Hz}, 1 \mathrm{H}), 1.51-1.38$ (m, 3H), 1.38-1.14 (m, 12H), 0.98$0.83(\mathrm{~m}, 9 \mathrm{H}) .{ }^{13} \mathrm{C} \mathrm{NMR}\left(100 \mathrm{MHz}, \mathrm{CDCl}_{3}\right) \delta=137.1,129.5,118.8$, 103.6, 81.9, 50.2, 48.3, 46.4, 44.6, 36.3, 33.9, 32.0, 31.9, 31.7, 26.2, 25.4, 24.9, 23.2, 23.2, 23.0, 14.1, 14.0, 13.9.

Compound 9d. ESIMS: $m / z 317[\mathrm{M}+\mathrm{H}]^{+}$. HREIMS: $m / z$ 317.2800, calcd. for $\mathrm{C}_{17} \mathrm{H}_{37} \mathrm{~N}_{2} \mathrm{O}_{3} \mathrm{~m} / \mathrm{z}$ 317.2804. ${ }^{1} \mathrm{H}$ NMR (400 $\left.\mathrm{MHz}, \mathrm{CDCl}_{3}\right) \delta=3.28(\mathrm{~s}, 3 \mathrm{H}), 2.72(\mathrm{dd}, J=11.9,4.0 \mathrm{~Hz}, 1 \mathrm{H}), 2.61$ $(\mathrm{dtd}, J=18.5,11.5,7.0 \mathrm{~Hz}, 2 \mathrm{H}), 2.50(\mathrm{dd}, J=11.9,8.5 \mathrm{~Hz}, 1 \mathrm{H})$, $2.30(\mathrm{t}, J=7.3 \mathrm{~Hz}, 2 \mathrm{H}), 2.22(\mathrm{~s}, 6 \mathrm{H}), 1.79-1.45(\mathrm{~m}, 10 \mathrm{H}), 1.36(\mathrm{~s}$, $3 \mathrm{H}), 1.35-1.22(\mathrm{~m}, 2 \mathrm{H}), 1.16(\mathrm{~s}, 3 \mathrm{H}), 0.91(\mathrm{t}, J=7.0 \mathrm{~Hz}, 3 \mathrm{H}) .{ }^{13} \mathrm{C}$ NMR (100 MHz, $\left.\mathrm{CDCl}_{3}\right) \delta=103.5,78.5,50.8,49.6,45.5,45.5$, 43.5, 35.4, 34.8, 32.5, 27.8, 26.5, 26.3, 23.6, 23.4, 14.3.

Compound 9e. ESIMS: $m / z 359[\mathrm{M}+\mathrm{H}]^{+}$. HREIMS: $m / z$ 359.3277, calcd. for $\mathrm{C}_{20} \mathrm{H}_{43} \mathrm{~N}_{2} \mathrm{O}_{3} \mathrm{~m} / \mathrm{z}$ 359.3274. ${ }^{1} \mathrm{H}$ NMR (400 $\left.\mathrm{MHz}, \mathrm{CDCl}_{3}\right) \delta=3.29(\mathrm{~s}, 3 \mathrm{H}), 2.75(\mathrm{dd}, J=11.9,4.1 \mathrm{~Hz}, 1 \mathrm{H})$, 2.68-2.54 (m, 2H), $2.50(\mathrm{dd}, J=11.9,8.4 \mathrm{~Hz}, 1 \mathrm{H}), 2.31(\mathrm{t}, J=7.2$ $\mathrm{Hz}, 2 \mathrm{H}), 2.22$ (s, 6H), 2.02-1.94 (m, 1H), 1.94-1.84 (m, 1H), 1.66 $(\mathrm{p}, J=7.4 \mathrm{~Hz}, 2 \mathrm{H}), 1.59-1.50(\mathrm{~m}, 4 \mathrm{H}), 1.39-1.30(\mathrm{~m}, 4 \mathrm{H}), 1.29(\mathrm{~s}$, $3 \mathrm{H}), 1.30-1.15(\mathrm{~m}, 6 \mathrm{H}), 0.92(\mathrm{t}, J=7.1 \mathrm{~Hz}, 3 \mathrm{H}), 0.89(\mathrm{t}, J=6.7 \mathrm{~Hz}$, $3 \mathrm{H}) .{ }^{13} \mathrm{C} \mathrm{NMR}\left(100 \mathrm{MHz}, \mathrm{CDCl}_{3}\right) \delta=102.2,81.9,58.3,50.7,49.0$, 48.6, 45.5, 45.5, 39.0, 36.4, 32.1, 31.5, 25.6, 25.0, 24.9, 23.2, 23.1, 18.9, 14.1, 14.0.

Compound 9f. ESIMS: $m / z$ $401[\mathrm{M}+\mathrm{H}]^{+}$. HREIMS: $m / z$ 401.3739, calcd. for $\mathrm{C}_{23} \mathrm{H}_{49} \mathrm{~N}_{2} \mathrm{O}_{3} \mathrm{~m} / \mathrm{z}$ 401.3743. ${ }^{1} \mathrm{H}$ NMR (400 $\left.\mathrm{MHz}, \mathrm{CDCl}_{3}\right) \delta=3.31(\mathrm{~s}, 3 \mathrm{H}), 3.16-3.07(\mathrm{~m}, 1 \mathrm{H}), 3.09(\mathrm{dd}, J=$ 11.9, $5.6 \mathrm{~Hz}, 1 \mathrm{H}), 3.06-2.96(\mathrm{~m}, 1 \mathrm{H}), 2.83(\mathrm{dd}, J=12.2,6.3 \mathrm{~Hz}$, $1 \mathrm{H}), 2.72-2.55(\mathrm{~m}, 3 \mathrm{H}), 2.38(\mathrm{~s}, 6 \mathrm{H}), 2.05($ broad s, 2H), 1.93-1.79 (m, 1H), 1.80-1.65 (m, 2H), 1.66-1.56 (m, 2H), 1.54-1.17 (m, $16 \mathrm{H}), 0.92(\mathrm{t}, J=7.0 \mathrm{~Hz}, 6 \mathrm{H}), 0.90(\mathrm{t}, J=6.9 \mathrm{~Hz}, 3 \mathrm{H}) .{ }^{13} \mathrm{C} \mathrm{NMR}$ $\left(100 \mathrm{MHz}, \mathrm{CDCl}_{3}\right) \delta=130.0,119.0,103.7,82.1,50.3,48.6,45.8$, $45.8,36.5,32.2$, 32.0, 29.9, 26.3, 25.6, 25.5, 25.2, 23.5, 23.4, 23.3, 14.3, 14.2, 14.1 .

Compound 9g. ESIMS: $m / z$ 359 $[\mathrm{M}+\mathrm{H}]^{+}$. HREIMS: $m / z$ 359.2913, calcd. for $\mathrm{C}_{19} \mathrm{H}_{39} \mathrm{~N}_{2} \mathrm{O}_{4} \mathrm{~m} / \mathrm{z}$ 359.2910. ${ }^{1} \mathrm{H}$ NMR (400 $\left.\mathrm{MHz} \mathrm{CDCl}_{3}\right) \delta=3.71(\mathrm{t}, J=4.7 \mathrm{~Hz}, 4 \mathrm{H}), 3.28(\mathrm{~s}, 3 \mathrm{H}), 2.75-2.56$ 
(m, 3H), $2.51(\mathrm{dd}, J=11.8,8.7 \mathrm{~Hz}, 1 \mathrm{H}), 2.44($ broad s, 4H), 2.39 $(\mathrm{t}, J=7.3 \mathrm{~Hz}, 2 \mathrm{H}), 2.27-2.15(\mathrm{~m}, 1 \mathrm{H}), 1.78-1.47(\mathrm{~m}, 7 \mathrm{H}), 1.36(\mathrm{~s}$, $3 \mathrm{H}), 1.38-1.23(\mathrm{~m}, 4 \mathrm{H}), 1.17(\mathrm{~s}, 3 \mathrm{H}), 0.91(\mathrm{t}, J=7.0 \mathrm{~Hz}, 3 \mathrm{H}) .{ }^{13} \mathrm{C}$ NMR (100 MHz, $\left.\mathrm{CDCl}_{3}\right) \delta=103.4,77.9,66.9,66.9,53.8,53.8$, 48.3, 34.9, 31.8, 27.5, 26.2, 23.2, 23.1, 23.0, 13.9 .

Compound 9h. ESIMS: $m / z 397[\mathbf{M}+\mathrm{H}]^{+}$. HREIMS: $m / z$ 397.3427, calcd. for $\mathrm{C}_{23} \mathrm{H}_{45} \mathrm{~N}_{2} \mathrm{O}_{3} \mathrm{~m} / \mathrm{z}$ 397.3430. ${ }^{1} \mathrm{H}$ NMR (400 $\mathrm{MHz}, \mathrm{CDCl}_{3}, 1: 1$ mixture of 2 diastereoisomers) $\delta=3.32$ (s, $3 \mathrm{H}), 3.17-3.09(\mathrm{~m}, 2 \mathrm{H}), 3.04-2.96(\mathrm{~m}, 2 \mathrm{H}), 2.98-2.79(\mathrm{~m}, 5 \mathrm{H})$, 2.32-2.20 (m, 1H), 2.20-2.09 (m, 2H), 1.93-1.83 (m, 1H), 1.84$1.70(\mathrm{~m}, 4 \mathrm{H}), 1.70-1.56(\mathrm{~m}, 3 \mathrm{H}), 1.56-1.42(\mathrm{~m}, 3 \mathrm{H}), 1.38(\mathrm{~s}, 3 \mathrm{H})$, 1.36-1.24 (m, 9H), 0.99-0.87 (m, 6H). ${ }^{13} \mathrm{C}$ NMR (100 MHz, $\left.\mathrm{CDCl}_{3}\right) \delta=101.4$, 81.8, 77.3, 54.1, 54.0, 50.0, 49.0, 48.9, 36.9, 36.2, 31.8, 31.3, 25.4, 24.8, 24.0, 23.3, 23.2, 23.2, 18.8, 14.1, 13.9.

Compound 9i. ESIMS: $m / z 352[\mathrm{M}+\mathrm{H}]^{+}$. HREIMS: $m / z$ 352.2604, calcd. for $\mathrm{C}_{19} \mathrm{H}_{34} \mathrm{~N}_{3} \mathrm{O}_{3} \mathrm{~m} / \mathrm{z}$ 352.2600. ${ }^{1} \mathrm{H}$ NMR (400 $\left.\mathrm{MHz}, \mathrm{CDCl}_{3}\right) \delta=7.47(\mathrm{~s}, 1 \mathrm{H}), 7.05(\mathrm{~s}, 1 \mathrm{H}), 6.91(\mathrm{~s}, 1 \mathrm{H}), 4.04(\mathrm{t}, J$ $=6.9 \mathrm{~Hz}, 2 \mathrm{H}), 3.29(\mathrm{~s}, 3 \mathrm{H}), 2.72(\mathrm{dd}, J=11.9,4.3 \mathrm{~Hz}, 1 \mathrm{H}), 2.57(\mathrm{t}$, $J=6.8 \mathrm{~Hz}, 2 \mathrm{H}), 2.50(\mathrm{dd}, J=11.9,7.8 \mathrm{~Hz}, 1 \mathrm{H}), 2.15(\mathrm{dd}, J=14.2$, 9.4 Hz, 1H), 2.00-1.87 (m, 3H), 1.78-1.43 (m, 14H), $1.29(\mathrm{~s}, 3 \mathrm{H})$. ${ }^{13} \mathrm{C}$ NMR $\left(100 \mathrm{MHz}, \mathrm{CDCl}_{3}\right) \delta=137.2,129.4,118.8,102.2$, 83.1, 50.7, 48.7, 46.6, 44.7, 40.1, 39.6, 35.0, 33.0, 31.2, 30.4, 30.3, 30.0, 22.4, 19.0 .

Compound 9j. ESIMS: $m / z 298[\mathrm{M}+\mathrm{H}]^{+}$. HREIMS: $m / z$ 298.2133, calcd. for $\mathrm{C}_{15} \mathrm{H}_{28} \mathrm{~N}_{3} \mathrm{O}_{3} \mathrm{~m} / \mathrm{z}$ 298.2131. ${ }^{1} \mathrm{H}$ NMR (400 $\left.\mathrm{MHz}, \mathrm{CDCl}_{3}\right) \delta=7.50(\mathrm{~s}, 1 \mathrm{H}), 7.05(\mathrm{~s}, 1 \mathrm{H}), 6.91(\mathrm{~s}, 1 \mathrm{H}), 4.04(\mathrm{t}, J$ $=6.9 \mathrm{~Hz}, 2 \mathrm{H}), 3.29(\mathrm{~s}, 3 \mathrm{H}), 2.74(\mathrm{dd}, J=12.0,4.2 \mathrm{~Hz}, 1 \mathrm{H}), 2.58(\mathrm{t}$, $J=6.9 \mathrm{~Hz}, 2 \mathrm{H}), 2.52(\mathrm{dd}, J=12.0,8.0 \mathrm{~Hz}, 1 \mathrm{H}), 2.45(\operatorname{broad~s}, 1 \mathrm{H})$, 2.02-1.91 (m, 3H), $1.71(\mathrm{t}, J=12.7 \mathrm{~Hz}, 1 \mathrm{H}), 1.54(\mathrm{dd}, J=13.0,4.7$ $\mathrm{Hz}, 1 \mathrm{H}), 1.37$ (s, 3H), 1.30 (s, 3H), 1.17 (s, 3H). ${ }^{13} \mathrm{C}$ NMR (100 $\left.\mathrm{MHz}, \mathrm{CDCl}_{3}\right) \delta=137.2,129.4,118.8,101.8,77.9,50.2$, 48.7, 46.2, 44.5, 39.2, 35.1, 27.4, 22.7, 18.9 .

Compound 9k. ESIMS: $m / z$ 450, $452\left(3: 1\right.$ ratio) $[\mathrm{M}+\mathrm{H}]^{+}$. HREIMS: $m / z$ 450.2526, calcd. for $\mathrm{C}_{24} \mathrm{H}_{37}{ }^{35} \mathrm{ClN}_{3} \mathrm{O}_{3} \mathrm{~m} / \mathrm{z} 450.2523$. ${ }^{1} \mathrm{H}$ NMR $\left(400 \mathrm{MHz}, \mathrm{CDCl}_{3}\right) \delta=8.50(\mathrm{~d}, J=5.4 \mathrm{~Hz}, 1 \mathrm{H}), 7.95(\mathrm{~d}, J$ $=2.1 \mathrm{~Hz}, 1 \mathrm{H}), 7.79(\mathrm{~d}, J=8.9 \mathrm{~Hz}, 1 \mathrm{H}), 7.41($ broad s, $1 \mathrm{H}), 7.33$ (dd, $J=8.9,2.2 \mathrm{~Hz}, 1 \mathrm{H}), 6.34(\mathrm{~d}, J=5.5 \mathrm{~Hz}, 1 \mathrm{H}), 3.48-3.35(\mathrm{~m}$, $2 \mathrm{H}), 3.29$ (s, 3H), 3.01-2.90 (m, 1H), 2.91-2.81 (m, 1H), 2.80 (dd, $J=12.5,3.9 \mathrm{~Hz}, 1 \mathrm{H}), 2.69(\mathrm{dd}, J=12.1,7.8 \mathrm{~Hz}, 1 \mathrm{H}), 2.33(\mathrm{ddt}, J=$ $12.3,8.2,4.3 \mathrm{~Hz}, 1 \mathrm{H}), 2.03-1.91(\mathrm{~m}, 2 \mathrm{H}), 1.86(\mathrm{t}, J=12.6 \mathrm{~Hz}, 1 \mathrm{H})$, 1.83-1.70 (m, 2H), 1.67-1.59 (m, 1H), 1.56 (dd, $J=12.8,4.7 \mathrm{~Hz}$, $1 \mathrm{H}), 1.39(\mathrm{~s}, 3 \mathrm{H}), 1.37-1.22(\mathrm{~m}, 4 \mathrm{H}), 1.14(\mathrm{~s}, 3 \mathrm{H}), 0.84(\mathrm{t}, J=7.0$ $\mathrm{Hz}, 3 \mathrm{H}) .{ }^{13} \mathrm{C}$ NMR $\left(100 \mathrm{MHz}, \mathrm{CDCl}_{3}\right) \delta=151.6,150.4,147.7$, 135.2, 127.2, 125.8, 122.9, 117.6, 103.9, 98.5, 78.1, 50.8, 49.7, 48.7, 43.6, 35.3, 34.7, 32.5, 27.8, 26.9, 26.5, 23.5, 23.3, 14.2.

Compound 9l. ESIMS: $m / z$ 492, $494\left(3: 1\right.$ ratio) $[\mathrm{M}+\mathrm{H}]^{+}$. HREIMS: $m / z$ 492.3001, calcd. for $\mathrm{C}_{27} \mathrm{H}_{43}{ }^{35} \mathrm{ClN}_{3} \mathrm{O}_{3} \mathrm{~m} / \mathrm{z} 491.2993$. ${ }^{1} \mathrm{H}$ NMR $\left(400 \mathrm{MHz}, \mathrm{CDCl}_{3}\right) \delta=8.50(\mathrm{~d}, J=5.5 \mathrm{~Hz}, 1 \mathrm{H}), 7.95(\mathrm{~d}, J$ $=2.1 \mathrm{~Hz}, 1 \mathrm{H}), 7.75(\mathrm{~d}, J=8.9 \mathrm{~Hz}, 1 \mathrm{H}), 7.34(\mathrm{dd}, J=8.9,2.2 \mathrm{~Hz}$, $1 \mathrm{H}), 6.34(\mathrm{~d}, J=5.5 \mathrm{~Hz}, 1 \mathrm{H}), 3.50-3.32(\mathrm{~m}, 2 \mathrm{H}), 3.29(\mathrm{~s}, 3 \mathrm{H}), 2.95$ (ddd, $J=10.9,6.8,3.6 \mathrm{~Hz}, 1 \mathrm{H}), 2.91-2.81(\mathrm{~m}, 1 \mathrm{H}), 2.83(\mathrm{dd}, J=$ 12.0, 3.7 Hz, 1H), 2.68 (dd, $J=12.2,8.2 \mathrm{~Hz}, 1 \mathrm{H}), 2.15-2.03(\mathrm{~m}$, $1 \mathrm{H}), 2.01-1.92(\mathrm{~m}, 2 \mathrm{H}), 1.94-1.85(\mathrm{~m}, 1 \mathrm{H}), 1.72(\mathrm{t}, J=12.7 \mathrm{~Hz}$, $1 \mathrm{H}), 1.56(\mathrm{dd}, J=13.0,4.8 \mathrm{~Hz}, 1 \mathrm{H}), 1.52-1.42(\mathrm{~m}, 1 \mathrm{H}), 1.42-1.31$ $(\mathrm{m}, 3 \mathrm{H}), 1.31(\mathrm{~s}, 3 \mathrm{H}), 1.28-1.06(\mathrm{~m}, 9 \mathrm{H}), 0.91(\mathrm{t}, J=7.1 \mathrm{~Hz}, 3 \mathrm{H})$, $0.83(\mathrm{t}, J=7.0 \mathrm{~Hz}, 3 \mathrm{H}) .{ }^{13} \mathrm{C} \mathrm{NMR}\left(100 \mathrm{MHz}, \mathrm{CDCl}_{3}\right) \delta=151.6$, 150.4, 147.7, 135.2, 129.8, 125.4, 122.9, 117.6, 102.1, 98.3, 81.8,
51.0, 49.5, 48.7, 43.6, 38.7, 36.3, 32.3, 31.6, 27.0, 25.5, 24.8, 23.2, 23.1, 18.9, 14.1, 14.0.

Compound 9m. ESIMS: $m / z$ 534, $536\left(3: 1\right.$ ratio) $[\mathrm{M}+\mathrm{H}]^{+}$. HREIMS: $m / z$ 534.3466, calcd. for $\mathrm{C}_{30} \mathrm{H}_{49}{ }^{35} \mathrm{ClN}_{3} \mathrm{O}_{3} m / z 534.3462$. ${ }^{1} \mathrm{H} \mathrm{NMR}\left(400 \mathrm{MHz}, \mathrm{CDCl}_{3}\right) \delta=8.50(\mathrm{~d}, J=1.7 \mathrm{~Hz}, 1 \mathrm{H}), 7.96(\mathrm{~s}$, $1 \mathrm{H}), 7.84(\mathrm{~d}, J=9.1 \mathrm{~Hz}, 1 \mathrm{H}), 7.35(\mathrm{~d}, J=9.0 \mathrm{~Hz}, 1 \mathrm{H}), 6.33$ (d, $J=$ $5.8 \mathrm{~Hz}, 1 \mathrm{H}), 3.51-3.34(\mathrm{~m}, 2 \mathrm{H}), 3.25(\mathrm{~s}, 3 \mathrm{H}), 3.03-2.92(\mathrm{~m}, 1 \mathrm{H})$, 2.92-2.78 (m, 2H), 2.74-2.62 (m, 1H), 2.39-2.27 (m, 1H), $1.88(\mathrm{t}, J$ $=12.7 \mathrm{~Hz}, 1 \mathrm{H}), 1.74(\mathrm{t}, J=12.4 \mathrm{~Hz}, 2 \mathrm{H}), 1.64-1.53(\mathrm{~m}, 1 \mathrm{H}), 1.53-$ $1.42(\mathrm{~m}, 1 \mathrm{H}), 1.41-1.09(\mathrm{~m}, 19 \mathrm{H}), 0.91(\mathrm{t}, J=6.7 \mathrm{~Hz}, 3 \mathrm{H}), 0.83$ (broad t, $J=6.1 \mathrm{~Hz}, 6 \mathrm{H}) .{ }^{13} \mathrm{C} \mathrm{NMR}\left(100 \mathrm{MHz}, \mathrm{CDCl}_{3}\right) \delta=151.7$, 150.3, 147.9, 135.6, 129.7, 126.2, 116.8, 115.3, 103.4, 98.1, 81.9, 50.5 , 48.9, 48.4, 36.2, 33.2, 32.1, 31.8, 31.7, 26.1, 25.4, 24.9, 23.2, 23.2, 23.0, 14.1, 14.0, 13.9.

Compound 9n. ESIMS: $m / z$ 464, 466 (3:1 ratio) $[\mathrm{M}+\mathrm{H}]^{+}$. HREIMS: $m / z$ 464.2683 calcd. for $\mathrm{C}_{25} \mathrm{H}_{39}{ }^{35} \mathrm{ClN}_{3} \mathrm{O}_{3} \mathrm{~m} / \mathrm{z} 464.2680$. ${ }^{1} \mathrm{H} \mathrm{NMR}\left(400 \mathrm{MHz}, \mathrm{CDCl}_{3}\right) \delta=8.49(\mathrm{~d}, J=5.5 \mathrm{~Hz}, 1 \mathrm{H}), 7.96(\mathrm{~d}, J$ $=2.1 \mathrm{~Hz}, 1 \mathrm{H}), 7.83(\mathrm{~d}, J=8.9 \mathrm{~Hz}, 1 \mathrm{H}), 7.36(\mathrm{dd}, J=8.9,2.2 \mathrm{~Hz}$, $1 \mathrm{H}), 6.37(\mathrm{~d}, J=5.5 \mathrm{~Hz}, 1 \mathrm{H}), 3.33(\mathrm{t}, J=6.5 \mathrm{~Hz}, 2 \mathrm{H}), 3.30(\mathrm{~s}, 3 \mathrm{H})$, $2.83(\mathrm{dd}, J=12.0,4.0 \mathrm{~Hz}, 1 \mathrm{H}), 2.82-2.67$ (m, 2H), 2.63 (dd, $J=$ $12.1,7.8 \mathrm{~Hz}, 1 \mathrm{H}$ ), 2.30 (ddt, $J=12.3,8.4,4.4 \mathrm{~Hz}, 1 \mathrm{H}$ ), 1.91-1.79 (m, 3H), 1.82-1.69 (m, 4H), 1.68-1.56 (m, 2H), $1.36(\mathrm{~s}, 3 \mathrm{H}), 1.34-$ $1.23(\mathrm{~m}, 5 \mathrm{H}), 1.16(\mathrm{~s}, 3 \mathrm{H}), 0.90(\mathrm{t}, J=7.0 \mathrm{~Hz}, 3 \mathrm{H}) .{ }^{13} \mathrm{C} \mathrm{NMR}(100$ $\left.\mathrm{MHz} \mathrm{CDCl}_{3}\right) \delta=151.5,150.4,147.8,135.6,129.8,125.6,122.2$, 116.9, 110.0, 103.3, 98.6, 77.9, 49.9, 49.1, 48.3, 42.8, 34.9, 34.3, 31.8, 27.4, 26.3, 26.1, 25.8, 23.1, 22.9, 13.9.

Compound 9o. ESIMS: $m / z$ 506, $508\left(3: 1\right.$ ratio) $[\mathrm{M}+\mathrm{H}]^{+}$. HREIMS: $m / z$ 506.3151, calcd. for $\mathrm{C}_{28} \mathrm{H}_{45}{ }^{35} \mathrm{ClN}_{3} \mathrm{O}_{3} m / z$ 506.3149. ${ }^{1} \mathrm{H}$ NMR $\left(400 \mathrm{MHz}, \mathrm{CDCl}_{3}\right) \delta=8.50(\mathrm{~d}, J=5.4 \mathrm{~Hz}, 1 \mathrm{H}), 7.96(\mathrm{~d}, J$ $=2.2 \mathrm{~Hz}, 1 \mathrm{H}), 7.77(\mathrm{~d}, J=8.9 \mathrm{~Hz}, 1 \mathrm{H}), 7.36(\mathrm{dd}, J=8.9,2.2 \mathrm{~Hz}$, $1 \mathrm{H}), 6.38(\mathrm{~d}, J=5.5 \mathrm{~Hz}, 1 \mathrm{H}), 3.33(\mathrm{t}, J=6.5 \mathrm{~Hz}, 2 \mathrm{H}), 3.30(\mathrm{~s}, 3 \mathrm{H})$, $2.83(\mathrm{dd}, J=12.1,4.0 \mathrm{~Hz}, 1 \mathrm{H}), 2.73(\mathrm{t}, J=6.6 \mathrm{~Hz}, 2 \mathrm{H}), 2.60(\mathrm{dd}, J$ $=12.1,7.9 \mathrm{~Hz}, 1 \mathrm{H}), 2.11-1.98(\mathrm{~m}, 2 \mathrm{H}), 1.93-1.81(\mathrm{~m}, 3 \mathrm{H}), 1.77-$ $1.65(\mathrm{~m}, 3 \mathrm{H}), 1.58(\mathrm{dd}, J=13.1,4.9 \mathrm{~Hz}, 1 \mathrm{H}), 1.55-1.38(\mathrm{~m}, 3 \mathrm{H})$, 1.37-1.32 (m, 4H), 1.30 (s, 3H), 1.28-1.17 (m, 5H), $0.91(\mathrm{t}, J=7.1$ $\mathrm{Hz}, 3 \mathrm{H}),(\mathrm{t}, J=7.0 \mathrm{~Hz}, 3 \mathrm{H}) .{ }^{13} \mathrm{C} \mathrm{NMR}\left(100 \mathrm{MHz}, \mathrm{CDCl}_{3}\right) \delta=$ 151.8, 150.2 147.7, 135.6, 129.8, 125.6, 122.3, 116.9, 102.0, 98.5, 81.8, 50.6, 49.1, 48.7, 42.9, 38.5, 36.3, 32.3, 31.5, 26.5, 25.9, 25.5, 24.8, 23.2, 23.1, 18.9, 14.1, 13.9 .

Compound 9p. ESIMS: $m / z$ 548, 550 (3:1 ratio) $[\mathrm{M}+\mathrm{H}]^{+}$. HREIMS: $m / z$ 548.3619, calcd. for $\mathrm{C}_{31} \mathrm{H}_{51}{ }^{35} \mathrm{ClN}_{3} \mathrm{O}_{3} m / z$ 548.3619. ${ }^{1} \mathrm{H}$ NMR $\left(400 \mathrm{MHz}, \mathrm{CDCl}_{3}\right) \delta=8.51(\mathrm{dd}, J=5.5,1.7 \mathrm{~Hz}, 1 \mathrm{H}), 7.95$ $(\mathrm{s}, 1 \mathrm{H}), 7.77(\mathrm{~d}, J=9.0 \mathrm{~Hz}, 1 \mathrm{H}), 7.36(\mathrm{dd}, J=8.9,2.2 \mathrm{~Hz}, 1 \mathrm{H})$, $6.38(\mathrm{~d}, J=5.4 \mathrm{~Hz}, 1 \mathrm{H}), 3.33(\mathrm{t}, J=6.7 \mathrm{~Hz}, 2 \mathrm{H}), 3.30(\mathrm{~s}, 3 \mathrm{H}), 2.79$ (dd, $J=13.3,4.0 \mathrm{~Hz}, 1 \mathrm{H}), 2.76-2.69(\mathrm{~m}, 2 \mathrm{H}), 2.60(\mathrm{dd}, J=12.0$, $7.8 \mathrm{~Hz}, 1 \mathrm{H}), 2.32-2.18(\mathrm{~m}, 1 \mathrm{H}), 1.91-1.79(\mathrm{~m}, 4 \mathrm{H}), 1.78-1.66(\mathrm{~m}$, $4 \mathrm{H}), 1.68-1.53(\mathrm{~m}, 2 \mathrm{H}), 1.50-1.35(\mathrm{~m}, 2 \mathrm{H}), 1.37-1.14(\mathrm{~m}, 14 \mathrm{H})$, 0.95-0.80 (m, 9H). $\left.{ }^{13} \mathrm{C} \mathrm{NMR} \mathrm{(100} \mathrm{MHz,} \mathrm{CDCl}_{3}\right) \delta=151.9,150.0$, 147.9, 135.6, 125.6, 122.2, 103.5, 98.6, 81.9, 50.1, 49.1, 48.3, 42.8, 36.3 , 33.6, 32.0, 31.8, 31.7, 26.1, 25.9, 25.4, 24.9, 24.8, 23.2, 23.1, 23.0, 14.1, 13.9, 13.8 .

Compound 9q. ESIMS: $m / z$ 422, 424 (3:1 ratio) $[\mathrm{M}+\mathrm{H}]^{+}$. HREIMS: $m / z$ 422.2212, calcd. for $\mathrm{C}_{22} \mathrm{H}_{33}{ }^{35} \mathrm{ClN}_{3} \mathrm{O}_{3} \mathrm{~m} / \mathrm{z} 422.2210$. ${ }^{1} \mathrm{H}$ NMR $\left(400 \mathrm{MHz}, \mathrm{CDCl}_{3}\right) \delta=8.49(\mathrm{~d}, J=5.5 \mathrm{~Hz}, 1 \mathrm{H}), 7.96(\mathrm{~d}, J$ $=2.1 \mathrm{~Hz}, 1 \mathrm{H}), 7.81(\mathrm{~d}, J=8.9 \mathrm{~Hz}, 1 \mathrm{H}), 7.36(\mathrm{dd}, J=8.9,2.1 \mathrm{~Hz}$, $1 \mathrm{H}), 6.37(\mathrm{~d}, J=5.6 \mathrm{~Hz}, 1 \mathrm{H}), 5.93($ broad s, $1 \mathrm{H}), 3.37-3.26(\mathrm{~m}$, $2 \mathrm{H}), 3.30(\mathrm{~s}, 3 \mathrm{H}), 2.84(\mathrm{dd}, J=12.1,4.0 \mathrm{~Hz}, 1 \mathrm{H}), 2.75(\mathrm{td}, J=6.5$, 
$1.7 \mathrm{~Hz}, 2 \mathrm{H}), 2.62(\mathrm{dd}, J=12.1,7.9 \mathrm{~Hz}, 1 \mathrm{H}), 2.13-2.03(\mathrm{~m}, 1 \mathrm{H})$, 1.93 (broad s, 1H), 1.89-1.81 (m, 2H), 1.80-1.71 (m, 3H), 1.60 (dd, $J=12.7,5.1 \mathrm{~Hz}, 1 \mathrm{H}), 1.37$ (s, 3H), 1.32 (s, 3H), 1.17 (s, 3H). ${ }^{13} \mathrm{C} \mathrm{NMR}\left(100 \mathrm{MHz}, \mathrm{CDCl}_{3}\right) \delta=152.1,150.2,147.8,135.5,125.4$, 121.8, 117.0, 102.0, 98.7, 80.0, 50.4, 49.2, 48.7, 43.0, 39.4, 35.2, 27.4, 26.8, 26.1, 25.9, 22.7, 18.9 .

Compound 9r. ESIMS: $m / z$ 474 $[\mathrm{M}+\mathrm{H}]^{+}$. HREIMS: $m / z$ 474.3333, calcd. for $\mathrm{C}_{27} \mathrm{H}_{44} \mathrm{~N}_{3} \mathrm{O}_{4} \mathrm{~m} / \mathrm{z}$ 474.3332. ${ }^{1} \mathrm{H}$ NMR (400 $\mathrm{MHz}, \mathrm{CDCl}_{3}, 1: 1$ mixture of 2 diastereoisomers) $\delta=8.52(\mathrm{~d}, J=$ $2.4 \mathrm{~Hz}, 1 \mathrm{H}), 7.92(\mathrm{dd}, J=8.2,1.8 \mathrm{~Hz}, 1 \mathrm{H}), 7.30(\mathrm{dd}, J=8.2,4.2$ $\mathrm{Hz}, 1 \mathrm{H}), 6.33$ (d, $J=2.5 \mathrm{~Hz}, 1 \mathrm{H}), 6.28$ (d, $J=2.5 \mathrm{~Hz}, 1 \mathrm{H}), 6.04$ (d, $J=8.3 \mathrm{~Hz}, 1 \mathrm{H}), 3.89(\mathrm{~s}, 3 \mathrm{H}), 3.67-3.58(\mathrm{~m}, 1 \mathrm{H}), 3.27$ (s, 3H), 2.71 $(\mathrm{dd}, J=11.9,3.8 \mathrm{~Hz}, 1 \mathrm{H}), 2.66-2.56(\mathrm{~m}, 2 \mathrm{H}), 2.50(\mathrm{dd}, J=11.9$, $8.6 \mathrm{~Hz}, 1 \mathrm{H}), 2.22-2.13(\mathrm{~m}, 1 \mathrm{H}), 1.77-1.57(\mathrm{~m}, 7 \mathrm{H}), 1.54(\mathrm{dd}, J=$ 13.0, 4.7 Hz, 1H), 1.34 (s, 3H), 1.34-1.23 (m, 8H), $1.15(\mathrm{~s}, 3 \mathrm{H})$, $0.89(\mathrm{t}, J=7.0 \mathrm{~Hz}, 3 \mathrm{H}) .{ }^{13} \mathrm{C}$ NMR $\left(100 \mathrm{MHz}, \mathrm{CDCl}_{3}\right) \delta=159.4$, 145.0, 144.3, 134.5, 129.9, 129.7, 121.8, 103.5, 96.8, 91.6, 78.0, 55.2 , 50.1, 49.9, 48.2, 48.0, 34.8, 34.7, 34.4, 31.8, 27.5, 26.2, 23.1, 22.9, 20.5, 13.9 .

Compound 9s. ESIMS: $m / z 516[\mathrm{M}+\mathrm{H}]^{+}$. HREIMS: $m / z$ 516.3804, calcd. for $\mathrm{C}_{30} \mathrm{H}_{50} \mathrm{~N}_{3} \mathrm{O}_{4} \mathrm{~m} / \mathrm{z}$ 516.3801. ${ }^{1} \mathrm{H}$ NMR (400 $\mathrm{MHz}, \mathrm{CDCl}_{3}, 1: 1$ mixture of 2 diastereoisomers) $\delta=8.52$ (dd, $J$ $=3.7,1.6 \mathrm{~Hz}, 1 \mathrm{H}), 7.92(\mathrm{dd}, J=8.2,1.7 \mathrm{~Hz}, 1 \mathrm{H}), 7.30(\mathrm{dd}, J=8.2$, $4.2 \mathrm{~Hz}, 1 \mathrm{H}), 6.36-6.31(\mathrm{~m}, 1 \mathrm{H}), 6.29(\mathrm{dd}, J=4.0,2.5 \mathrm{~Hz}, 1 \mathrm{H})$, 6.05-5.97 (m, 1H), $3.89(\mathrm{~s}, 3 \mathrm{H}), 3.68-3.59(\mathrm{~m}, 1 \mathrm{H}), 3.27$ and 3.26 $(\mathrm{s}, 3 \mathrm{H}), 2.79(\mathrm{~d}, J=12.0 \mathrm{~Hz}, 1 \mathrm{H}), 2.72-2.60(\mathrm{~m}, 2 \mathrm{H}), 2.54(\mathrm{t}, J=$ $10.1 \mathrm{~Hz}, 1 \mathrm{H}), 2.03-1.93(\mathrm{~m}, 1 \mathrm{H}), 1.91-1.81(\mathrm{~m}, 1 \mathrm{H}), 1.77-1.54$ $(\mathrm{m}, 8 \mathrm{H}), 1.32$ and $1.30(\mathrm{~s}, 3 \mathrm{H}), 1.27$ and $1.26(\mathrm{~s}, 3 \mathrm{H}), 1.34-0.89$ $(\mathrm{m}, 10 \mathrm{H}), 0.89-0.85(\mathrm{~m}, 6 \mathrm{H}) .{ }^{13} \mathrm{C}$ NMR $\left(100 \mathrm{MHz}, \mathrm{CDCl}_{3}\right) \delta=$ $159.4,145.0,144.3$, 134.8, 129.9, 129.7, 123.2, 121.8, 118.9, 102.6, 96.8, 81.9, 55.2, 50.5, 50.0, 48.6, 48.1, 48.0, 36.3, 34.4, $32.1,31.5,25.5,24.8,23.2,20.5,18.8,14.1,14.0$.

\subsection{Molecular modeling}

Molecular modeling calculations were performed on SGI Origin 200 8XR12000 and E4 Server Twin $2 \times$ Dual Xeon-5520, equipped with two nodes. Each node: $2 \times$ Intel ${ }^{\circledR}$ Xeon ${ }^{\circledR}$ QuadCore E5520-2.26Ghz, 36 GB RAM. The molecular modeling graphics were carried out on SGI Octane 2 workstations.

Apparent $\mathrm{p} K_{\mathrm{a}}$ and $\log D$ values of new endoperoxides were calculated by using ACD/Percepta software. ${ }^{30}$ Accordingly, percentage of neutral/ionized forms were computed at $\mathrm{pH} 7.4$ (blood), at pH 7.2 (cytoplasm) and at pH 5.5 ( $P f$ food vacuole) using the Henderson-Hasselbalch equation.

5.3.1 Conformational analysis. The new endoperoxides were built, taking into account the prevalent ionic forms at the considered different $\mathrm{pH}$ values, using the Insight 2005 Builder module (Accelrys Software Inc., San Diego).

Since 9h, 9r and 9s were tested as mixture of two diastereomers, both diastereomers of these compounds were built. Atomic potentials and charges were assigned using the CFF91 force field. ${ }^{31}$ The conformational space of the compounds was sampled through 200 cycles of simulated annealing $(\varepsilon=1)$. In simulated annealing, the temperature is altered in time increments from an initial temperature to a final temperature by adjusting the kinetic energy of the structure (by rescaling the velocities of the atoms). The following protocol was applied: the system was heated up to $1000 \mathrm{~K}$ over $2000 \mathrm{fs}$ (time step $=1.0 \mathrm{fs}$ ); the temperature of $1000 \mathrm{~K}$ was applied to the system for $2000 \mathrm{fs}$ (time step $=1.0 \mathrm{fs}$ ) with the aim of surmounting torsional barriers; successively, temperature was linearly reduced to $300 \mathrm{~K}$ in $1000 \mathrm{fs}$ (time step $=1.0 \mathrm{fs}$ ). Resulting conformations were then subjected to molecular mechanic (MM) energy minimization within Insight 2005 Discover module (CFF91 force field; $\varepsilon=1$ ) until the maximum RMS derivative was less than $0.001 \mathrm{kcal}^{-1}$, using Conjugate Gradient ${ }^{32}$ as minimization algorithm. All MM conformers were then subjected to a full geometry optimization by semiempirical calculations, using the quantum mechanical method PM7 ${ }^{33}$ in the Mopac2012 package $^{34}$ and EF $^{35}$ (Eigenvector Following routine) as geometry optimization algorithm. GNORM value was set to 0.01 . To reach a full geometry optimization the criteria for terminating all optimizations was increased by a factor of 100, using the keyword PRECISE.

Resulting conformers were ranked by their potential energy values (i.e., $\Delta E$ from the global energy minimum). All PM7 conformers within $5 \mathrm{kcal} \mathrm{mol}^{-1}$ from the global minimum were classified on the basis of: (i) 1,2-dioxane ring conformation; (ii) intramolecular hydrogen bonds and (iii) distance between endoperoxide oxygens (O1 or $\mathrm{O} 2$ ) and possible partners for a 'through space' intramolecular radical shift $(\leq 3 \AA)$. Then, the occurrence rates were calculated.

5.3.2 Docking procedure. In order to further investigate the role of the conformational behavior on antimalarial activity, docking studies were carried out on 9c di-protonated form and on 9r diastereomer protonated form in complex with heme, using a docking methodology (Affinity, SA_Docking; Insight 2005, Accelrys, San Diego, CA) which considers all the systems flexible (i.e., ligand and heme). Atomic potentials of heme were assigned using the Heme29.frc; ${ }^{36}$ a force field including heme parameters and atomic partial charges were assigned using the quantum mechanical method PM7. Heme apparent $\mathrm{p} K_{\mathrm{a}}$ values were calculated by using ACD/Percepta software. Accordingly, one propionic chain was considered protonated and the heme net total charge was set at +1 . Although during the subsequent dynamic docking protocol all the systems were perturbed by means of Monte Carlo and simulated annealing procedures, a reasonable starting structure is anyway required. Thus, the PM7 lowest energy conformer of $\mathbf{9 c}$ and 9 r diastereomers meeting the hypothesized pharmacophoric requirements for antimalarial activity was selected as the ligand starting conformation. The ligand was then placed above the heme, taking as template the crystal structure of a peroxo-bridged heme-copper dinuclear complex (CSD code UKACIS) and considering the O2/O7 iron coordination complex. During the docking calculations, all atoms in the complex were left free to move during the entire docking calculations with the exception of heme pyrrolic carbons, which were kept fixed and, in order to avoid unrealistic results, the distance between the iron and the interacting oxygens (i.e. $\mathrm{O} 2$ and $\mathrm{O} 7)$ was restrained within $2.0 \AA$ (100-1000 kcal mol ${ }^{-1} \AA^{-2}$ ). The Cell_Multipole method ${ }^{37}$ has been used to calculate nonbond interactions. A Monte Carlo/minimization approach for the random generation of a maximum of 20 acceptable ligand/heme complexes was used. During the first 
step, starting from the previously obtained roughly docked structures, the ligand was moved by a random combination of translation, rotation, and torsional changes (Flexible_Ligand option, considering all rotatable bonds) to sample both the conformational space of the ligand and its orientation with respect to the heme (MxRChange $=3 \AA$; MxAngChange $=180^{\circ}$ ). During this step, van der Waals (vdW) and Coulombic terms were scaled to a factor of 0.1 to avoid very severe divergences in the Coulombic and vdW energies. If the energy of a complex structure resulting from random moves of the ligand was higher by the energy tolerance parameter than the energy of the last accepted structure, it was not accepted for minimization. To ensure a wide variance of the input structures to be successively minimized, an energy tolerance value of $10^{6} \mathrm{kcal} \mathrm{mol}^{-1}$ from the previous structure has been used. After the energy minimization step (conjugate gradient, 2500 iterations, $\varepsilon=1$ ), the Metropolis test, at a temperature of $310 \mathrm{~K}$, and a structure similarity check (rms tolerance of $0.3 \mathrm{kcal} \AA^{-1}$ ) were applied to select the 20 acceptable structures. Each subsequent structure was generated from the last accepted structure. All the accepted complexes resulting from the Monte Carlo/minimization approach were subjected to a molecular dynamics simulated annealing protocol, including 5 ps of a dynamic run divided in 50 stages (100 fs each) during which the temperature of the system was linearly decreased from 500 to $300 \mathrm{~K}$ (Verlet velocity integrator; time step of $1.0 \mathrm{fs}$ ). Molecular dynamics calculations were performed using a constant temperature and constant volume (NVT) statistical ensemble, and the direct velocity scaling as temperature control method (temp window, $10 \mathrm{~K}$ ). In the first stage, initial velocities were randomly generated from the Boltzmann distribution according to the desired temperature, while during the subsequent stages initial velocities were generated from dynamics restart data. A temperature of $500 \mathrm{~K}$ was applied to surmount torsional barriers, thus allowing an unconstrained rearrangement of the ligand and the heme (initial vdW and Coulombic scale factors of 0.1). Successively temperature was linearly reduced to $300 \mathrm{~K}$ in $5 \mathrm{ps}$, and concurrently the scale factors have been similarly decreased from their initial values (0.1) to their final values (1.0). A final round of $10^{5}$ minimization steps (conjugate gradient, $\varepsilon=1$ ) followed the last dynamics steps, and the minimized structures were saved in a trajectory file. After this procedure, the resulting docked structures were ranked by their conformational energy. The complex with the best conformational energy was selected as structure representing the most probable binding mode. The resulting complex was then subjected to a full geometry optimization by semi-empirical calculations, using the quantum mechanical method PM7 ${ }^{33}$ in the Mopac2012 package ${ }^{34}$ and EF $^{35}$ (Eigenvector Following routine) as geometry optimization algorithm. GNORM value was set to 0.01 . To reach a full geometry optimization the criteria for terminating all optimizations was increased by a factor of 100, using the keyword PRECISE.

\subsection{Parasite culture and drug bioassay}

Two in vitro standardized strains of $P f$, the chloroquine sensitive D10 and the chloroquine resistant W2 strains, were cultured as described by Trager \& Jensen. ${ }^{38}$ Parasite cultures were maintained at 5\% hematocrit (human type A-positive red blood cells) in RPMI 1640 (EuroClone) medium with the addition of 1\% AlbuMax (Invitrogen, Italy), 0.01\% hypoxanthine, 20 $\mathrm{mm}$ HEPES and $2 \mathrm{~mm}$ glutamine, at $37{ }^{\circ} \mathrm{C}$ in a standard gas mixture consisting of $1 \% \mathrm{O}_{2}, 5 \% \mathrm{CO}_{2}$, and $94 \% \mathrm{~N}_{2}$. Compounds were dissolved in DMSO, mix well, and then diluted with medium to achieve the required concentrations (final DMSO concentration $<1 \%$, which is nontoxic to the parasite). Drugs were placed in sterile 96 well flat-bottom microplates (EuroClone) and serial dilutions made. Asynchronous cultures with parasitemia of $1-1.5 \%$ and $1 \%$ final hematocrit were aliquoted into the plates and incubated for $72 \mathrm{~h}$ at $37{ }^{\circ} \mathrm{C}$ in an hermetic chamber gassed with the standard gas mixture. Parasite growth was determined spectrophotometrically (OD650) by measuring the activity of the parasite lactate dehydrogenase ( $\mathrm{pLDH})$, according to a modified version of Makler's method in control and drug-treated cultures. ${ }^{39}$ Antiplasmodial activity is expressed as the $50 \%$ inhibitory concentrations $\left(\mathrm{IC}_{50}\right)$. Each $\mathrm{IC}_{50}$ value is the mean \pm standard deviation of at least three separate experiments performed in duplicate. ${ }^{40}$

\subsection{In vitro mammalian cell toxicity assay}

HMEC-1 is a long-term cell line of human dermal microvascular endothelial cells immortalized by SV 40 large $\mathrm{T}$ antigen, kindly provided by the Centres for Disease Control and Prevention, Atlanta, GA, USA. ${ }^{41}$ Cells were maintained in standard conditions at $37{ }^{\circ} \mathrm{C}$ in $5 \% \mathrm{CO}_{2}$ incubator in MCDB 131 medium (GIBCO-BRL, Paisley, Scotland) supplemented with $10 \%$ fetal calf serum (HyClone, Celbio, Milan, Italy), $10 \mathrm{ng} \mathrm{ml}^{-1}$ epidermal growth factor (PreproTech, Rocky Hill, NY, USA), $1 \mu \mathrm{g} \mathrm{ml}$ hydrocortisone (Sigma Italia, Milan, Italy), $2 \mathrm{mM}$ glutamine (EuroClone, Pero, Italy), $100 \mathrm{U} \mathrm{ml}^{-1} \mathrm{PEN}, 100 \mathrm{mg} \mathrm{ml}^{-1}$ STR (EuroClone) and $20 \mathrm{mM}$ Hepes buffer, pH 7.3 (EuroClone).

For the toxicity experiments, HMEC- 1 at $1.0 \times 10^{4}$ cells/100 $\mu \mathrm{l}$ per well were plated in 96-well plates and incubated at 37 ${ }^{\circ} \mathrm{C}, 5 \% \mathrm{CO}_{2}$ overnight. Cells were then treated for $72 \mathrm{~h}$ with different doses of test compounds. Three independent experiments in duplicate were performed. The MTT (Sigma) cytotoxicity assay was used to measure cell viability as described elsewhere. ${ }^{42}$ The cytotoxicity is expressed as $\mathrm{IC}_{50}$, which is the dose of compound necessary to inhibit cell growth by $50 \%$.

5.5.1 Selectivity (SI) index. The Selectivity Index (SI) evaluates the toxicity impact of the active compounds against normal human cells compared to the toxicity against the parasite and allows the assessment of the selectivity of these drugs for the parasite. The SI was calculated as the ratio between the cytotoxic $\mathrm{IC}_{50}$ values against HMEC-1 and the parasitic $\mathrm{IC}_{50}$ values against the CQ-S (D10) or the CQ-R (W2) strains.

\section{Acknowledgements}

This work was supported by: the Ministero degli Affari Esteri (MAE), Rome contribution PGR00124 (Design and development of new antimalarial leads for chloroquine-resistant plasmodium strains) to CT; EU project Bluegenics (grant number 
311848) to OTS and CF; Italian MIUR (FIRB project: RBFR12WB3W_003) to MP; (PRIN project 2010C2LKKJ_006) to YC and DT. DPS would like to thank Erasmus Mundus India4EuII program for a fellowship. The authors are particularly thankful to AVIS Comunale Milano for collecting blood samples for parasite culture.

\section{Notes and references}

1 M. Jung, H. Kim, K. Lee and M. Park, Mini-Rev. Med. Chem., 2003, 3, 159-165.

2 WHO, World Malaria Report 2013, ISBN: 9789241564694.

3 Y. Tang, Y. Dong and J. L. Vennerstrom, Med. Res. Rev., 2004, 24, 425-448.

4 http://www.ebi.ac.uk/chembl/malaria/.

5 (a) F. Cafieri, E. Fattorusso, O. Taglialatela-Scafati and

A. Ianaro, Tetrahedron, 1999, 55, 7045-7056; (b)

E. Fattorusso, S. Parapini, C. Campagnuolo, N. Basilico,

O. Taglialatela-Scafati and D. Taramelli, J. Antimicrob. Chemother., 2002, 50, 883-888; (c) C. Fattorusso, G. Campiani, B. Catalanotti, M. Persico, N. Basilico, S. Parapini, D. Taramelli, C. Campagnuolo, E. Fattorusso, A. Romano and O. Taglialatela-Scafati, J. Med. Chem., 2006, 49, 7088-7094.

6 O. Taglialatela-Scafati, E. Fattorusso, A. Romano, F. Scala, V. Barone, P. Cimino, E. Stendardo, B. Catalanotti, M. Persico and C. Fattorusso, Org. Biomol. Chem., 2010, 8, 846-856.

7 M. Persico, A. Quintavalla, F. Rondinelli, C. Trombini, M. Lombardo, C. Fattorusso, V. Azzarito, D. Taramelli, S. Parapini, Y. Corbett, G. Chianese, E. Fattorusso and O. Taglialatela-Scafati, J. Med. Chem., 2011, 54, 8526-8540.

8 M. Persico, S. Parapini, G. Chianese, C. Fattorusso, M. Lombardo, L. Petrizza, A. Quintavalla, F. Rondinelli, N. Basilico, D. Taramelli, C. Trombini, E. Fattorusso and O. Taglialatela-Scafati, Eur. J. Med. Chem., 2013, 70, 875-886.

9 M. Lombardo, D. P. Sonawane, A. Quintavalla, C. Trombini,

D. D. Dhavale, D. Taramelli, Y. Corbett, F. Rondinelli, C. Fattorusso, M. Persico and O. Taglialatela-Scafati, Eur. J. Org. Chem., 2014, 1607-1614.

10 (a) G. H. Posner, J. N. Cumming, P. Ploypradith and C. H. Oh, J. Am. Chem. Soc., 1995, 117, 5885-5886; (b) Y. Wu, Z. Y. Yue and Y. L. Wu, Angew. Chem., Int. Ed., 1999, 38, 2580-2582; (c) D. Y. Wang and Y. L. Wu, Chem. Commun., 2000, 2193-2194; (d) S. Kapetanaki and C. Varotsis, J. Med. Chem., 2001, 44, 3150-3156; (e) S. A.-L. Laurent, C. Loup, S. Mourgues, A. Robert and B. Meunier, ChemBioChem, 2005, 6, 653-658; ( $f$ ) B. Meunier and A. Robert, Acc. Chem. Res., 2010, 43, 1444-1451.

11 K. Haynes, R. Cheu, K.-W. N'Da, P. Coghi and D. Monti, Infect. Disord.: Drug Targets, 2013, 13, 217-277.

12 Both 3,4-cis and 3,4-trans esters 4 possessing one methyl substituent on $\mathrm{C} 3\left(\mathrm{R}^{1}=\mathrm{Me}\right)$ and two propyl substituents on $\mathrm{C} 6\left(\mathrm{R}^{2}=\mathrm{R}^{3}=n\right.$-propyl), resulted completely inactive $\left(\mathrm{IC}_{50}>10 \mu \mathrm{M}\right)$ against D10 and W2 $P f$ strains.

13 T. Rodrigues, M. Prudếncio, R. Moreira, M. M. Mota and F. Lopes, J. Med. Chem., 2012, 55, 995-1012.
14 N. Vale, R. Moreira and P. Gomes, Eur. J. Med. Chem., 2009, 44, 937-953.

15 (a) Evaluation of drug candidates for preclinical development: pharmacokinetics, metabolism, pharmaceutics, and toxicology, ed. C. Han, C. B. Davis and B. Wang, John Wiley \& Sons, 2010, pp. 1-289; (b) Drug-like properties: concepts, structure design and methods, ed. E. H. Kerns and L. Di, Elsevier, 2008, pp. 1-552.

16 (a) F. Benoit-Vical, J. Lelièvre, A. Berry, C. Deymier, O. DechyCabaret, J. Cazelles, C. Loup, A. Robert, J. F. Magnaval and B. Meunier, Antimicrob. Agents Chemother., 2007, 51, 14631472; (b) C. Singh, H. Malik and S. K. Puri, Bioorg. Med. Chem., 2004, 12, 1177-1182.

17 T. J. Egan, J. M. Combrinck, J. Egan, G. R. Hearne, H. M. Marques, S. Ntenteni, B. T. Sewell, P. J. Smith, D. Taylor, D. A. van Schalkwyk and J. C. Walden, Biochem. J., 2002, 365, 343-347.

18 E. L. Dodd and D. S. Bohle, Chem. Commun., 2014, 50, 1376513768.

19 T. Chishiro, Y. Shimazaki, F. Tani, Y. Tachi, Y. Naruta, S. Karasawa, S. Hayami and Y. Maeda, Angew. Chem., Int. Ed., 2003, 42, 2788-2791.

20 (a) P. P. McCann, C. J. Bacchi, W. L. Hanson, G. D. Cain, H. C. Nathan, S. H. Hutner and A. Sjoerdsma, Adv. Polyamine Res., 1981, 3, 97-110; (b) J. M. Whaun and N. D. Brown, J. Pharmacol. Exp. Ther., 1985, 233, 507-511.

21 (a) P. M. O'Neill, V. E. Barton, S. A. Ward and J. Chadwick, in Treatment and Prevention of Malaria, ed. H. M. Staines and S. Krishna, Springer, 2012, pp. 19-44; (b) S. A. Charman, S. Arbe-Barnes, I. C. Bathurst, R. Brun, M. Campbell, W. N. Charman, F. C. Chiu, J. Chollet, J. C. Craft, D. J. Creek, Y. Dong, H. Matile, M. Maurer, J. Morizzi, T. Nguyen, P. Papastogiannidis, C. Scheurer, D. M. Shackleford, K. Sriraghavan, L. Stingelin, Y. Tang, H. Urwyler, X. Wang, K. L. White, S. Wittlin, L. Zhou and J. L. Vennerstrom, Proc. Natl. Acad. Sci. U. S. A., 2011, 108, 4400-4405; (c) R. E. Coleman, A. K. Nath, I. Schneider, G. H. Song, T. A. Klein and W. K. Milhous, Am. J. Trop. Med. Hyg., 1994, 50, 646-653.

22 H. C. Ha, N. S. Sirisoma, P. Kuppusamy, J. L. Zweier, P. M. Woster and R. A. Casero Jr, Proc. Natl. Acad. Sci. U. S. A., 1998, 95, 11140-11145.

23 (a) K. C. Das and H. P. Misra, Mol. Cell. Biochem., 2004, 262, 127-133; (b) Y. Maeda and K. U. Ingold, J. Am. Chem. Soc., 1980, 102, 328-331; (c) D. Griller, J. A. Howard, P. R. Marriott and J. C. Scaiano, J. Am. Chem. Soc., 1981, 103, 619-623; (d) J. M. Tanko, R. Friedline, N. K. Suleman and N. Castagnoli Jr, J. Am. Chem. Soc., 2001, 123, 58085809; (e) U. Pischel and W. M. Nau, J. Am. Chem. Soc., 2001, 123, 9727-9737.

24 (a) R. M. Reguera, B. L. Tekwani and R. Balaña-Fouce, Comp. Biochem. Physiol., Part C: Toxicol. Pharmacol., 2005, 140, 151164; (b) J. Niemand, P. Burger, B. K. Verlinden, J. Reader, A. M. Joubert, A. Kaiser, A. I. Louw, K. Kirk, O. Phanstiel and L. M. Birkholtz, Antimicrob. Agents Chemother., 2013, 57, 2874-2877. 
25 (a) F. Dubar, T. J. Egan, B. Pradines, D. Kuter, K. K. Ncokazi, D. Forge, J. F. Paul, C. Pierrot, H. Kalamou, J. Khalife, E. Buisine, C. Rogier, H. Vezin, I. Forfar, C. Slomianny, X. Trivelli, S. Kapishnikov, L. Leiserowitz, D. Dive and C. Biot, ACS Chem. Biol., 2011, 18, 275-287; (b) E. Morelli, S. Gemma, R. Budriesi, G. Campiani, E. Novellino, C. Fattorusso, B. Catalanotti, S. S. Coccone, S. Ros, G. Borrelli, M. Persico, I. Fiorini, V. Nacci, P. Ioan, A. Chiarini, M. Hamon, A. Cagnotto, T. Mennini, C. Fracasso, M. Colovic, S. Caccia and S. Butini, J. Med. Chem., 2009, 52, 3548-3562; (c) S. Butini, G. Campiani, S. Franceschini, F. Trotta, V. Kumar, E. Guarino, G. Borrelli, I. Fiorini, E. Novellino, C. Fattorusso, M. Persico, N. Orteca, K. Sandager-Nielsen, T. A. Jacobsen, K. Madsen, J. Scheel-Kruger and S. Gemma, J. Med. Chem., 2010, 53, 4803-4807.

26 (a) R. Capela, G. G. Cabal, P. J. Rosenthal, J. Gut, M. M. Mota, R. Moreira, F. Lopes and M. Prudencio, Antimicrob. Agents Chemother., 2011, 55, 4698-4706; (b) F. Grellepois, P. Grellier, D. Bonnet-Delpon and J. P. Begue, ChemBioChem, 2005, 6, 648-652; (c) J. J. Walsh, D. Coughlan, N. Heneghan, C. Gaynor and A. Bell, Bioorg. Med. Chem. Lett., 2007, 17, 3599-3602.

27 (a) F. W. Muregi and A. Ishih, Drug Dev. Res., 2010, 71, 20-32;

(b) E. L. Flannery, A. K. Chatterjee and E. A. Winzeler, Nat. Rev. Microbiol., 2013, 11, 849-862.

28 (a) C. Loup, J. Lelievre, F. Benoit-Vical and B. Meunier, Antimicrob. Agents Chemother., 2007, 51, 3768-3770; (b) F. Coslédan, L. Fraisse, A. Pellet, F. Guillou, B. Mordmuller, P. G. Kremsner, A. Moreno, D. Mazier, J. P. Maffrand and B. Meunier, Proc. Natl. Acad. Sci. U. S. A., 2008, 105, 17579-17584.
29 N. C. Araújo, V. Barton, M. Jones, P. A. Stocks, S. A. Ward, J. Davies, P. G. Bray, A. E. Shone, M. L. Cristiano and P. M. O'Neill, Bioorg. Med. Chem. Lett., 2009, 19, 2038-2043. $30 \mathrm{ACD} /$ Percepta, version 14.0.0, Advanced Chemistry Development, Inc., Toronto, ON, Canada, 2013, http:// www.acdlabs.com.

31 J. R. Maple, M. J. Hwang, T. P. Stockfisch, U. Dinur, M. Waldman, C. S. Ewig and A. T. Hagler, J. Comput. Chem., 1994, 15, 162-182.

32 R. Fletcher, in Practical Methods of Optimization, John Wiley \& Sons, New York, 1980, vol. 1.

33 J. J. Stewart, J. Mol. Model., 2013, 19, 1-32.

34 J. J. Stewart, MOPAC2012, Stewart Computational Chemistry, Colorado Springs, CO, USA, 2012, http:// www.openmopac.net.

35 J. Baker, J. Comput. Chem., 1986, 7, 385-395.

36 H. D. Holtje and C. Fattorusso, Pharm. Acta Helv., 1998, 72, 271-277.

37 H. Q. Ding, N. Karasawa and W. A. Goddard III, J. Chem. Phys., 1992, 7, 4309-4315.

38 W. Trager and J. B. Jensen, Science, 1976, 193, 673-675.

39 M. T. Makler, J. M. Ries, J. A. Williams, J. E. Bancroft, R. C. Piper, B. L. Gibbins and D. J. Hinrichs, Am. J. Trop. Med. Hyg., 1993, 48, 739-741.

40 A. Sparatore, N. Basilico, S. Parapini, S. Romeo, F. Novelli, F. Sparatore and D. Taramelli, Bioorg. Med. Chem., 2005, 13, 5338-5345.

41 E. W. Ades, F. J. Candal, R. A. Swerlick, V. G. George, S. Summers, D. C. Bosse and T. J. Lawley, J. Invest. Dermatol., 1992, 99, 683-690.

42 S. D'Alessandro, M. Gelati, N. Basilico, E. A. Parati, R. K. Haynes and D. Taramelli, Toxicology, 2007, 241, 66-74. 